Dzieje Najnowsze, Rocznik L - 2018, 1

PL ISSN 0419-8824

Tomasz Sikorski

Uniwersytet Szczeciński

\title{
Fronda. Rozłam w Stowarzyszeniu PAX w 1955 roku. (Geneza - przebieg - konsekwencje)
}

\begin{abstract}
Abstrakt: Artykuł stanowi próbę wielopłaszczyznowego ukazania podłoża wewnątrzśrodowiskowego konfliktu w Stowarzyszeniu PAX, który w 1955 r. doprowadził do poważnego w skutkach rozłamu. W pierwszej części tekstu skoncentrowano uwagę na genezie grupy, która opuści PAX. W drugiej części artykułu dokonano analizy procesu wewnętrznej dekompozycji Stowarzyszenia PAX, który doprowadził do opuszczenia jego szeregów przez tzw. frondę. Omówiono zarówno podstawowe źródła konfliktu, jak też przebieg wewnętrznego sporu, z uwzględnieniem optyki dwóch stron konfliktu.
\end{abstract}

Słow a kluczowe: Stowarzyszenie PAX, fronda, katolicy świeccy w PRL, publicystyka polityczna, ruchy społeczno-polityczne.

Abstract: The article is an attempt at multi-faceted presentation of the underlying causes of the internal conflict within the PAX Association, which in 1955 led to a split with serious consequences. The first part focuses on the origins of the group which would leave PAX. The second part is and analysis of the process of internal decomposition of the PAX Association, which led the so-called Fronde to leave its ranks. The text discusses both the basic causes of the conflict, and its internal course, seen from the both sides.

Keyw ords: PAX Association, Fronde, lay Catholics in the Polish People's Republic, political journalism, socio-political movements.

Geneza tzw. pierwszej frondy, środowiska rozłamowego w Stowarzyszeniu PAX, uformowanego w „przeddzień” polskiego Października '56, sięga swoim rodowodem końca lat czterdziestych. Pierwszym, faktycznym laboratorium idei dla młodych postępowych katolików było „Słowo Akademickie” (wcześniej „Życie Akademickie”) - dodatek do „Słowa Powszechnego”, gdzie poruszano 
nie tylko mniej lub bardziej błahe problemy dotyczące ludzi młodych, ale również dokonywano krytycznych ocen francuskiego personalizmu, który kilkanaście lat później stanie się drogowskazem dla frondy, a potem zespołu „Więzi”. Następnie „młodzi” zbliżyli się do tygodnika „Dziś i Jutro”, mając nadzieję, że wypłyną na szerokie wody pracy publicystycznej i formacyjnej. Otrzymaja do dyspozycji „niezależną” od redakcji tygodnika kolumnę pt. „Z ubocza”. Pisywać do niej będa: Janusz Zabłocki, Jan Klimowski, Jan Gawlik i Ryszard Kiersnowski. W założeniu kolumna miała pełnić rolę „katolickiego trustu mózgów", miejsca ścierania się różnych poglądów spojonych chrześcijańską wizją stosunków społecznych i socjalizmem (a nawet marksizmem). Ciagle jeszcze było to środowisko „wolnych ptaków”, mocno eklektyczne, ciagle poszukujace ${ }^{1}$.

Do właściwej inicjacji ideowej dojść miało, jak wspominał po wielu latach Janusz Zabłocki, na letnim obozie ideowo-programowym w Rowach (sierpień 1948 r.), niedaleko Słupska. To tutaj Zabłocki poznał osobiście Tadeusza Mazowieckiego ${ }^{2}$. Łączyło ich już wówczas wspólne przekonanie o radykalnie społecznym podejściu do współczesności, potrzebie świeżego spojrzenia na katolicyzm, zerwania z integryzmem ${ }^{3}$. Podczas kolejnego spotkania, rok później na obozie w Zakopanem (sierpień 1949 r.), Zabłocki wygłosił referat pt. „Młodzież katolicka wobec młodzieży innych światopoglądów”, w którym zaakceptował ideały socjalizmu, a właściwie cały socjalistyczny ustrój społeczno-gospodarczy z jego fundamentami: społecznymi środkami produkcji, bezklasowym społeczeństwem, gospodarką planową i internacjonalizmem, jako jedynie słuszną alternatywę dla niebezpieczeństwa nacjonalizmu. Socjalistyczne credo nie oznaczało jednak przyjęcia całej marksistowskiej metodologii, przede wszystkim materializmu dialektycznego ${ }^{4}$. Byłoby to uproszczenie, dalece odległe zarówno od motywacji Zabłockiego, jak i przesłania jego „wczesnej publicystyki”.

U progu 1949 r. „postępowi katolicy” założyli własna, autonomiczna, kilkustronicową wkładkę do tygodnika „Dziś i Jutro”, pt. „Etap”, która w założeniu stać się miała wolna trybuną dla młodych publicystów paksowskich. „Etap” skupiał ludzi wywodzących się z różnych środowisk ${ }^{5}$. Część z nich, jak

1 J. Zabłocki, Mazowiecki mój przeciwnik (1), „Ład”, 21 X 1990, nr 42, s. 3; Załącznik do listu Janusza Zabłockiego do Tomasza Sikorskiego, 10 VII 2011 (w zbiorach prywatnych autora).

2 J. Zabłocki, Mazowiecki mój przeciwnik (1)..., s. 6; idem, Mazowiecki mój przeciwnik (2): Rowy, „Ład”, 28 X 1990, nr 43, s. 3; M. Strzelecka, Między minimalizmem a maksymalizmem. Dylematy ideowe Stanistawa Stommy i Janusza Zabłockiego, Toruń 2015, s. 105-106.

${ }_{3}$ J. Zabłocki, Mazowiecki mój przeciwnik (2)..., s. 3.

${ }^{4}$ Por. idem, Mazowiecki mój przeciwnik (4): Rozdroża roku 1949, „Ład”, 11 XI 1990, nr 45, s. 10. Warto zaznaczyć, że jeszcze w jednym z najwcześniejszych tekstów publicystycznych Zabłocki określał siebie mianem „twórczego marksisty”. Por. Gawor (J. Zabłocki), O Marksie $i$ marksistach. Felieton marksistowski, „Dziś i Jutro”, 21 III 1948, nr 12, s. 5.

${ }^{5}$ J. Zabłocki, Mazowiecki mój przeciwnik (4): Etap, „Ład”, 4 XI 1990, nr 44; A. Friszke, Między wojna a więzieniem 1945-1953. Młoda inteligencja katolicka, Warszawa 2015, s. 272-281. 
Janusz Zabłocki, miała za sobą akowskie doświadczenie, inni w działalności publicznej byli zupełnymi naturszczykami. Do współpracy włączyli się tak młodzi, zrewolucjonizowani katolicy, jak i socjaliści oraz marksiści. Program „Etapu” daleki był od jednoznaczności. Od samego początku cel sam w sobie stanowił ideowy eklektyzm, poszukiwanie źródeł i tradycji, do której można by się odnieść. Jednak bardzo szybko, głównie za sprawą Zabłockiego i jego tekstów, odkrywano znaną na rodzimym gruncie już od czasów dwudziestolecia ideę humanizmu integralnego Jacques'a Maritaina, francuskiego filozofa i teologa ${ }^{6}$.

Publicystyka Zabłockiego z tego okresu, tj. z lat 1949-1954, iść będzie jednak dwuwektorowo. Bronił przy różnych okazjach zdobyczy socjalizmu, „sojuszu robotniczo-chłopskiego”, „demokratycznych” wartości i zasad konstytucji z 1952 r., paradygmatów „demokracji ludowej”. Idąc z duchem czasów, a jednocześnie zgodnie $\mathrm{z}$ tonem nadawanym przez prasę partyjno-rządowa, przestrzegał przed niebezpieczeństwem rewizjonizmu niemieckiego i amerykańskimi imperialistami, którzy mieli zagrażać światowemu pokojowi (np. casus wojny w Korei) ${ }^{8}$.

Obecność podobnej retoryki odnajdziemy również w tekstach Tadeusza Mazowieckiego, publicysty już wówczas znanego, którego artykuły nierzadko otwierały kolejne numery „Dziś i Jutro”. Jednak znacznie bardziej ciekawy jest ten drugi wektor, który można by określić mianem „fermentu humanistycznego". Zarówno Zabłocki, jak i Mazowiecki w swoich tekstach, nie kryjąc socjalistycznych sympatii czy też społecznej wrażliwości, przekonywali wzorem personalistów francuskich (czasami nieświadomie) o potrzebie odrodzenia katolicyzmu, oczyszczenia go ze „starej rdzy” integryzmu. Humanizm chrześcijański miał być w swojej treści i powołaniu „radykalnym”, stanowić

${ }^{6}$ Zob. K. Zajczniewski (J. Zabłocki), Etap humanizmu chrześcijańskiego, „Dziś i Jutro”, 20 II 1949, nr 7, s. 7; idem, Chrześcijaństwo a świat wspótczesny, „Dziś i Jutro”, 8 V 1949, nr 18, s. 6; idem, Jeszcze o humanizmie chrześcijańskim, „Dziś i Jutro”, 9 X 1949, nr 40, s. 8; idem, Zadanie numer jeden, „Dziś i Jutro”, 20 XI 1949, nr 46, s. 6.

7 Zob. np.: J. Zabłocki, Wymowa historycznego zjazdu, „Dziś i Jutro”, 16 XI 1952, nr 46, s. 1-2; idem, O rozwoju świadomości społecznej katolików, „Dziś i Jutro”, 3 V 1953, nr 18, s. 10; idem, O boskim i cesarskim, „Dziś i Jutro”, 7 VI 1953, nr 23, s. 6-7; idem, Spotkanie z Leninem, „Dziś i Jutro”, 24 I 1954, nr 4, s. 1; idem, Sojusz robotniczo-chtopski warunkiem rozwoju wsi, „Dziś i Jutro”, 2 V 1954, nr 18, s. 4; idem, Szkoła władzy i rzqdzenia, „Dziś i Jutro”, 31 X 1954, nr 44, s. 1; idem, Refleksje pierwszomajowe, „Słowo Powszechne”, 1 V 1952, nr 103, s. 1; idem, Potrzeba wspótpracy, „Słowo Powszechne”, 3-4 I 1953, nr 3, s. 3; idem, Owoce hiszpańskiej krucjaty, „Słowo Powszechne”, 7-8 II 1953, nr 33, s. 3. Por. też: M. Strzelecka, op. cit., s. 126-129.

${ }^{8}$ Por. np.: J. Zabłocki, Nowocześni Krzyżacy z Bonn, „Słowo Powszechne”, 9 IV 1953, nr 82, s. 2; idem, Ogólnoludzkie braterstwo i duma narodowa, „Słowo Powszechne”, 12 VIII 1953, nr 189, s. 2; idem, Przeciw groźnej mistyfikacji, „Dziś i Jutro”, 21-28 XII 1952, nr 51-52, s. 6, 9; idem, Rozróżnienie, które jest gwarantem osiagnięć, „Dziś i Jutro”, 6 XII 1953, nr 49 , s. $1,11$.

${ }_{9}$ Por. A. Brzeziecki, Tadeusz Mazowiecki. Biografia naszego premiera, Kraków 2015, s. 59-60. 
wezwanie dla współczesnej cywilizacji. Rozładowanie „konserwatywnych oporów” w połączeniu z otwarciem na socjalizm stanowić miało siłe „ożywczą" i „dynamiczną. Mazowieckiemu bliższa była w tym czasie humanistyczna wizja socjalizmu, wypełnionego moralna - etyczna treścia. W ustroju socjalistycznym dostrzegał szansę na równość społeczna, likwidację dysproporcji, awans społeczny, bezpłatny dostęp do edukacji i służby zdrowia. Program reformy rolnej, uspołecznienia środków produkcji, uprzemysłowienia, którego Mazowiecki w swoich tekstach bronił, był tylko prostym następstwem zwycięstwa socjalizmu ${ }^{10}$. Tyle albo aż tyle. W centrum zainteresowania Mazowieckiego znajdowali się jednak nie system, ani ustrój, ale człowiek i wspólnota. I nie chodziło tutaj o ludzkość jako pojęcie abstrakcyjne, wyobcowane, nie miał też na myśli „proletariatu” (choć pojęciem tym często się posługiwał), ale „żywych ludzi”, nie indywidualne jednostki, ale człowieka ujmowanego jako jednostka, z własną osobowością i godnością. Odnosząc się krytycznie do kultury mieszczańskiej (także społeczeństwa mieszczańskiego, obyczajowości mieszczańskiej), domagał się, jak André Malraux (w Czasach pogardy [1935]), „żyzności”, uczynienia kultury bliższej człowiekowi, pełnej i prawdziwej. Słowem od strony humanistycznej socjalizm był dla Mazowieckiego „sprawa ludzką"11. Jednocześnie szukając współczesnego znaczenia socjalizmu, pytał

${ }_{10}$ Por. np.: T. Mazowiecki, Samodzielność myślenia, „Słowo Powszechne”, 23 X 1947, s. 3; idem, Jeszcze o samodzielności myślenia, „Słowo Powszechne”, 22 II 1948, s. 5; idem, Zagadnienie ustroju społeczno-gospodarczego $w$ projekcie Konstytucji, „Słowo Powszechne”, 20 II 1952, s. 3; idem, Urodzaj ludowego życia, „Wrocławski Tygodnik Katolicki”, 18 VII 1954, nr 29, s. 5-10; idem, Front tej samej walki, „Wrocławski Tygodnik Katolicki” 1954, s. 3; idem, Pomyśl z nami nad ta sprawa, „Wrocławski Tygodnik Katolicki”, 7 III 1954, nr 10, s. 3.

11 Por. np.: idem, Sens moralny, „Słowo Powszechne”, 30 V 1950, s. 1-2; idem, Zależność nierozerwalna, „Dziś i Jutro”, 29 IV 1951, nr 17, s. 1, 6; idem, „Być czymś”, „Słowo Powszechne”, 17 VII 1951, s. 3; idem, Świadectwo chrześcijańskie, „Wrocławski Tygodnik Katolicki”, 31 VII 1955, nr 31, s. 5-6; idem, O kulturze trzeba śmielej, „Wrocławski Tygodnik Katolicki”, 3 VII 1955, nr 27, s. 1-5; idem, Ku społeczeństwu funkcjonalistycznemu, „Dziś i Jutro”, 8 I 1950, nr 1, s. 1-2; idem, Kierunek myśli społecznej, „Dziś i Jutro”, 2 VII 1950, nr 26, s. 1-2; idem, Myśli z naszej drogi, „Dziś i Jutro”, 26 XI 1950, nr 47, s. 5. Bodaj największą niesławę przyniosła Mazowieckiemu broszura pt. Wróg pozostał ten sam (Warszawa 1952), która zredagował wspólnie z Zygmuntem Przetakiewiczem. Jest to zbiór wypowiedzi świeckich i duchownych afirmujących ustrój socjalistyczny i władzę komunistyczna. Przedmowę do tej książeczki napisał Mazowiecki. Można tam było przeczytać m.in.: „W roku 1952 historia dowodzi, że dokonane w Polsce przemiany społeczne sa nieodwracalne. W świat zaś wyzysku kapitalistycznego i kolonialnego coraz to mocniej uderza powiew buntu społecznego. Równocześnie też rzeczywistość międzynarodowa odsłania niebezpieczeństwo wojny, która byłaby wojną o grozie dotychczas niewyobrażalnej. Głosy odwetowców zachodnioniemieckich nie pozostają przy tym bez żadnych wątpliwości, co do ich jawnie antypolskich tendencji zaborczych. [...] Robota przeciwko Polsce, jej nowej linii rozwojowej, wychodzi z tych samych kół politycznych Zachodu, które przerażone przebiegająca przez cały świat fala przemian społecznych, wyciagnąwszy swe stare zawołanie bojowe o "niebezpieczeństwie czerwonej zarazy», usiłują wepchnać ludzkość w tragedię ogólnoświatowej wojny. [...] Te same siły zmierzają do wywołania w Polsce niepokoju 
o sens katolicyzmu. Podążając śladami Maritaina i Emmanuela Mouniera, przekonywał czytelników, że podnoszenie wiedzy religijnej powinno człowieka zbliżyć do Boga. Życie zgodne z nakazami moralności ewangelicznej, wypełnione autentyczna radościa, świadczyć miało o prawdziwej postawie chrześcijańskiej. Religia, podobnie jak cywilizacja - twierdził Mazowiecki znajduje się w ciagłym rozwoju, a zatem należało podążać za „duchem czasu”, nowoczesnymi tendencjami, które można było pogodzić z pozorna jedynie antynomią teocentryzmu i autonomią osoby ludzkiej ${ }^{12}$.

Marksizm z katolicyzmem nie muszą być jak ogień i woda - pisał Mazowiecki w 1950 r. - [...] Dlatego katolicy muszą podjąć trud wywalczenia humanistycznej płaszczyzny współzawodniczenia światopoglądów. Nie możemy się oglądać na nikogo. [...] postawa katolicka nie może być utożsamiana z postawą antyrewolucyjna, przeciwnie, że jest ona w pełni zdolna twórczo poświęcić pogłębić postawę rewolucyjną. [...] Walka [...] o personalizm w ustroju socjalistycznym jest zadaniem, które musimy wykonać ${ }^{13}$.

społecznego. [...] Polityce tej wiernie sekunduje emigracja polityczna. [...] Ideologia lancy ułańskiej na usługach kapitalistycznej wolności zasłoniła im historyczną szansę wydobycia Polski w wielowiekowych zaniedbań cywilizacyjnych. Kraj obchodzi ich dziś tylko w jednym wymiarze - władzy. Metro, Nowa Huta, zagospodarowanie Ziem Odzyskanych, likwidacja analfabetyzmu, wielkie nakłady pism Mickiewicza i Słowackiego i wiele naszych innych osiagnięć to dla nich tylko propaganda. [...] Sa wśród nas ludzie, którzy czasem skłonni są dawać wiarę owym podszeptom kwestionującym celowość i sensowność tego wysiłku. Ci ludzie muszą jednak wiedzieć, że tu koło się zamyka w jakiejś nieubłaganej logice. Posłuch wrogiej propagandzie wprowadza na stromą ścieżkę wiodąca poprzez osłabianie atmosfery współodpowiedzialności całego narodu za wspólne dzieło aż do dywersji gospodarczej, czy nawet politycznej. [...] Ważne jest dla nas wszystkich to, aby nie było wśród nas zjawiska ludzi wciagniętych w robotę dywersyjną i sabotażowa. Bo wszystkich ludzi nam potrzeba do pracy, do wielkiego wysiłku lepszej przyszłości”. Cyt. za: T. Mazowiecki, Z. Przetakiewicz, Wróg pozostat ten sam, Warszawa 1952, s. 6-17. „Czarną legendę” publicystyki Mazowieckiego z omawianego okresu wzmacniał tekst pt. Wnioski („Wrocławski Tygodnik Katolicki”, 27 IX 1953, nr 5, s. 3), w którym włączył się w ohydną nagonkę na biskupa kieleckiego Czesława Kaczmarka. Krytycznie o publicystyce Mazowieckiego sprzed 1956 r. pisali: F. Przytulski, „Obok wież Kościołów, kominy fabryk”. Działalność publicystyczna Tadeusza Mazowieckiego w latach 1947-1955, w: Sensus catholicus. Katolicy świeccy w Polsce Ludowej. Postawy - aktywność - myśl. Studia i szkice, red. R. Ptaszyński, T. Sikorski, Toruń 2014, s. 343-375; S. Cenckiewicz, Jak Mazowiecki zwalczat podziemie, „Do Rzeczy. Historia” 2013, nr 1, s. 10-13. Zob. też: R. Graczyk, Od uwikłania do autentyczności. Biografia polityczna Tadeusza Mazowieckiego, Poznań 2015, s. 30-48; A. Brzeziecki, op. cit., s. $49-68$.

12 T. Mazowiecki, „Gdybym miłości nie miał...” W sprawie artykułu $w$ „La Civilta Cattolica”, „Słowo Powszechne”, 8-9 XI 1951, s. 1; idem, Sprawa sumienia, „Wrocławski Tygodnik Katolicki”, 23 V 1954, nr 21; idem, Co daje katolikowi wiedza religijna, „Wrocławski Tygodnik Katolicki”, 1954, nr 11, s. 6-7; idem, Serce katolicyzmu, „Wrocławski Tygodnik Katolicki”, 3 V 1955, nr 19; idem, Świadectwo chrześcijańskie, „Wrocławski Tygodnik Katolicki”, 31 VII 1955, nr 31, s. 5-6.

${ }^{13}$ Cyt. za: idem, Kierunek myśli społecznej, „Dziś i Jutro”, 2 VII 1950, nr 26, s. 1-2. 
Podobnie myślał Zabłocki. Współczesna postawa „postępowych katolików” w przekonaniu Zabłockiego powinna być rewolucyjna (radykalna). Oczywiście w odniesieniu do rzeczywistości. Zabłocki uważał, że socjalizm, ze wszystkimi swoimi niedoskonałościami, w swojej treści jest ustrojem - systemem najbardziej prospołecznym, stojącym po stronie człowieka. Paradoks czasów stanowił fakt, że to marksiści stanęli na czele „obozu postępu” i to oni budowali zręby socjalizmu. Pomimo tej świadomości, przyznajmy nieco kłopotliwej, zważywszy na to, że pisał z perspektywy katolickiej, należało prowadzić z marksistami dialog, a nie ich zwalczać. Cel był przecież wspólny, tylko metody odmienne. Takiemu sposobowi myślenia sprzyjać miała historia. I tak Zabłocki na łamach „Tygodnika Powszechnego” przypomniał w cyklu artykułów postać Charles'a Péguy'ego, znanego francuskiego dramaturga, eseisty, ale przede wszystkim poety. Nie biografia Péguy'ego była jednak tutaj najistotniejsza, ale jego ideowe zakorzenienie, głęboka socjalistyczna intuicja (należał również do partii socjalistycznej i tworzył lewicujące pismo literackie „Les Cahiers de la Quinzaine"), połączona z chrześcijańskim wyznaniem wiary ${ }^{14}$. Innym razem, też w cyklu artykułów, powrócił do głośnej na przełomie XIX i XX w. sprawy potępienia przez papieża Piusa X francuskiej grupy „Sillon” - ruchu społecznego i politycznego, reprezentującego lewicową orientację chadecką ${ }^{15}$. Przyglądał się z uwagą francuskim katolikom, którzy podjęli po zakończeniu wojny współpracę $\mathrm{z}$,obozem rewolucji” ${ }^{\prime \prime}$.

Poglądy Zabłockiego ugruntowywały się jednak powoli, dopiero w trakcie studiów nad współczesną filozofią francuskiego personalizmu, i to już od końca lat czterdziestych. Recepcji personalizmu poświęcił kilka tekstów, a w $1951 \mathrm{r}$. przetłumaczył fragment głośnej książki Maritaina, pt. Du régime temporel et de la liberté (1933), który opublikował na łamach „Tygodnika Powszechnego"17. Od Maritaina zaczerpną podstawowy katalog zasad: 1) człowiek został obdarzony godnością 2) człowiek - osoba ludzka jest najważniejsza, a więc żaden system polityczny, także żadna wspólnota - np. naród nie może go sobie podporządkować; 3) człowiek jest częścia świata przyrody i podlega jej prawom; 4) głównym założeniem etyki jest jej uniwersalizm, a to oznacza, że etyka świecka powinna być oparta na wartościach i powinnościach chrześcijańskich; 5) zarówno liberalizm, jak i wszelkie odmiany totalitaryzmów to

${ }_{14}$ Por. M. Péguy, Przeciw nędzy, tłum. K. Zajczniewski (J. Zabłocki), „Dziś i Jutro”, 12 III 1950, nr 10, s. 4; K. Zajczniewski (J. Zabłocki), Sad nad Péguy, „Dziś i Jutro”, 13 VIII 1950, nr 32, s. 1, 3; idem, Życie, które byto spetnieniem powołania. W 80-ta rocznicę urodzin Karola Péguy, „Słowo Powszechne”, 1-11 II 1953, nr 8, s. 8; idem, Karol Péguy, „Tygodnik Powszechny", 20 VIII 1950, nr 34, s. 2, 10.

15 Por. J. Zabłocki, Sprawa „Sillon”, „Dziś i Jutro”, 15 X 1950, nr 41, s. 3; idem, Marc Sangnier $i$,Sillon”, „Słowo Powszechne”, 25 VII 1950, nr 201, s. 3; idem, Mazowiecki mój przeciwnik (6): Porozumienie i sprawa „Sillon”, „Ład”, 25 XI 1990, nr 47, s. 10.

16 Por. idem, Chrześcijanie - progresiści, „Dziś i Jutro”, 4 II 1951, nr 5, s. 5, 10.

17 J. Maritain, Wolność i osoba, tłum. J. Zabłocki, „Tygodnik Powszechny”, 21 I 1950, nr 3, s. 1. 
systemy niszczące osobowość i godność człowieka. Za Mounierem powtarzał, że katolicyzm nie powinien być wyobcowany ze współczesności. Należało wziąć w dłonie „włócznię, przywdzianą w rewolucyjną zbroję” i walczyć o osobę ludzką. „Nowa” walka klas w ujęciu personalistycznym oznaczać miała pobudzenie osobowości człowieka. Tylko wówczas socjalizm osiagnąłby pełnię moralnej treści. Sądził, że w sytuacji wzrostu dążeń proletariatu walczącego o wyzwolenie się z ucisku klasowego należy stanąc po stronie socjalizmu - najbardziej sprawiedliwego dla mas (ludzkości) ustroju. W ślad za tym przeorientował również metodę. Ideał sakralny, charakterystyczny dla teocentryzmu średniowiecznego, w nowych czasach należało zastapić metodą „świecka” i wykorzystując ja, kreować współczesną doktrynę społeczną katolicyzmu ${ }^{18}$.

Późna wiosną 1950 r. Zabłocki przystapił do elitarnego zespołu „Dziśs i Jutro". Kilka miesięcy później zmontował zespół samokształceniowy, nazwany prześmiewczo „Jaczejką. Jej trzon tworzyli: Wojciech Wieczorek (wówczas redaktor krakowskiego oddziału „Słowa Powszechnego”), Adam Pankiewicz (student dziennikarstwa na UJ), Tadeusz Myślik (świeżo upieczony absolwent AH, pracownik organizacyjny w krakowskim oddziale „Słowa Powszechnego"), Rudolf Buchała (absolwent prawa, założyciel katowickiego oddziału „Słowa Powszechnego”). Nieco później dojdą jeszcze: Jerzy Skwara, Zygmunt Drozdek, następnie Danuta Zabłocka-Skupieńska (siostra J. Zabłockiego), jej mąż Robert Skupieński (lekarz), reprezentanci warszawskiego środowiska socjologicznego: Wacław Makarczyk i Czesław Czapów ${ }^{19}$. W marcu 1952 r. do „Jaczejki” doszlusowali: Mazowiecki, Stefan Bakinowski i Ignacy Rutkiewicz. Grupa nie miała jasnego programu. Łączył ją krytyczny stosunek do stalinizmu, monizmowi materialistycznemu przeciwstawiano pluralizm światopoglądowy, totalizmowi - demokratyczny socjalizm i wielość dróg do jego osiagnięcia. Poddawano analizie „komunistyczną herezję”, prace dziewiętnastowiecznych anarchistów i ich współczesną wersję - tzw. wolszczyznę (poglądy kooperatysty anarchistycznego i spółdzielcy Jana Wolskiego), rewizjonizm (reformizm) Eduarda Bernsteina, wykładnię humanistycznego socjalizmu Jana Strzeleckiego, idee IV Międzynarodówki (krytyczne wobec stalinizmu, ciążące w kierunku trockizmu).

Zabłocki dostrzegał w „Jaczejce” praźródła frondy. Od samego początku bowiem członkowie środowiska sceptycznie, by nie powiedzieć krytycznie,

18 Por. przede wszystkim: J. Zabłocki, Anachronizm metody „sakralnej”, „Dziś i Jutro”, 11 XI 1951, nr 45, s. 3; idem, Personalizm i rewolucja, „Dziś i Jutro”, 25 XI 1951, nr 47, s. 3-4; idem, Uwagi o panujacej metodzie, „Dziś i Jutro”, 16 XII 1951, nr 50, s. 3; idem, Człowiek - jednostka i osoba, „Dziś i Jutro”, 20 I 1952, nr 3, s. 1, 4; idem, Natura ludzka, „Słowo Powszechne", 25-26 VIII 1951, nr 228, s. 3.

${ }_{19}$ Idem, Mazowiecki mój przeciwnik (8): Narodziny Frondy, „Ład”, 16 XII 1990, nr 50, s. 6; Załącznik do listu Janusza Zabłockiego do Tomasza Sikorskiego, 10 VII 2011 (w zbiorach prywatnych autora). 
patrzyli na rodowód „ruchu nienazwanego”. Raziły ich przedwojenne związi Piaseckiego i jego najbliższych zwolenników (ścisłe kierownictwo ruchu) z przedwojenną orientacja narodowo-radykalna, chłonna antysemityzmu i tendencji totalistycznych (wodzowskich). W rozumieniu Zabłockiego i Mazowieckiego „młodzi” mieli wnieść do ruchu postępowych katolików nowe siły witalne, ożenić socjalizm z prądami francuskiego personalizmu. Do pierwszego przesilenia doszło już po zarejestrowaniu Stowarzyszenia PAX, w 1952 r., w momencie dyskusji nad kolejną edycja „Wytycznych” - najważniejszego dokumentu ideowo-programowego środowiska. Między Piaseckim a „młodymi” - Mazowieckim (członkiem zespołu pracujacego nad tekstem) i Zabłockim pojawiły się pryncypialne różnice dotyczące relacji pomiędzy religią (katolicyzmem) a polityką. Piasecki uznawał za aksjomat obecność chrześcijaństwa w świecie. Był przekonany, iż dążenie do Boga wyraża się w służbie socjalizmowi i Kościołowi. Optyka „młodych” wyglądała zgoła odmiennie. Zabłocki nazwał ją sporem o „immanencję polityczną”. Opowiadał się wespół z Mazowieckim za pluralizmem światopoglądowym jako alternatywą dla wszelkich totalizmów (także światopoglądowych) i integryzmów (także katolickich). Z tego wynikała główna teza rodząca najwięcej wątpliwości u Piaseckiego i jego „drużyny”. A mianowicie katolicy mieli przede wszystkim służyć socjalizmowi. Nie istnieje bowiem chrześcijańska polityka, a jedynie chrześcijańska odpowiedzialność polityczna w życiu publicznym ${ }^{20}$. Co prawda Zabłocki i Mazowiecki podpisali się pod ostateczną wersją tekstu „Wytycznych”, ale obie strony sporu ideowego (także taktycznego) nie watpiły, że jest to „kompromis” osiagnięty na krótki czas. Piasecki miał świadomość różnic. Nie zamierzał jednak tracić coraz bardziej prężnego środowiska młodych radykałów i awansował Zabłockiego i Mazowieckiego na członków ścisłego kierownictwa PAX. Niebawem wysłał Mazowieckiego „na prowincję” - do Wrocławia, gdzie właśnie uruchomiono nowe czasopismo postępowych katolików - „Wrocławski Tygodnik Katolicki” (od 1957 r. „Wrocławski Tygodnik Katolików”). Mianowano go „naczelnym” nowego pisma. Natomiast Zabłocki został przeniesiony do Warszawy, otrzymał funkcję inspektora Stowarzyszenia PAX w województwach: lubelskim, olsztyńskim i wrocławskim ${ }^{21}$. Dzięki tej nominacji szybko zdobył popularność „w terenie”, także w Poznaniu, Szczecinie, Gdańsku i Koszalinie, gdzie pracował już wcześniej jako „kierownik terenowy” PAX. Z perspektywy czasu był to błąd Piaseckiego, który nie do końca wierzył w zdolności organizacyjne i siłę przekonywania Zabłockiego.

W każdym razie te roszady nie zahamowały „ruchów tektonicznych” w środowisku. Kolejne przesilenie było tylko kwestią czasu. Na uformowanie się opozycji wewnątrz PAX-u wpłynęły tėz fakty obiektywne. Przede

\footnotetext{
${ }^{20}$ J. Zabłocki, Mazowiecki mój przeciwnik (9): Spór o „immanencję polityczna”, „Ład”, 23-30 XII 1990, nr 51-52, s. 13.

${ }^{21}$ A. Micewski, Wspótrzadzić a nie ktamać. PAX i Znak w Polsce 1945-1976, Paryż 1978, s. 75.
} 
wszystkim hierarchiczna, niedemokratyczna, podporządkowana Piaseckiemu struktura stowarzyszenia. Działalność organizacyjna Stowarzyszenia PAX odbywała się w ramach Zespołu (wcześniej Zespół Centralny) liczącego początkowo kilkadziesiąt osób, a już w 1955 r., wraz z rozwojem organizacji, ponad 100 (w 1956 r. było to ok. 200 osób). Zespół miał charakter tylko i wyłącznie dyskusyjny i formacyjny. Trzon Zespołu stanowił niemal cały skład kierowniczy konspiracyjnej (wojennej) Konfederacji Narodu, uzupełniony o byłych członków Stronnictwa Narodowego, Narodowej Organizacji Wojskowej, Narodowych Sił Zbrojnych, organizacji katolickich i ok. 50 młodych działaczy niezwiązanych wcześniej z żadnymi organizacjami. Wszyscy członkowie stowarzyszenia wchodzili do Zespołów Terenowych - niższych ogniw organizacyjnych. Ich kierownicy nie pochodzili z wyborów, lecz byli mianowani osobiście przez Piaseckiego. Tam tez funkcjonowały oddziały wojewódzkie „Słowa Powszechnego”, kluby dyskusyjne, zespoły artystyczne. Wyższą formą organizacji było początkowo tzw. Rozszerzone Kierownictwo, a następnie Kolegium Funkcyjne (członkowie kierownictwa, inspektorzy terenowi, kierownicy wydziałów, kierownicy oddziałów wojewódzkich i samodzielnych instytucji PAX). Podobnie jak w Zespole, tak i tutaj decydujący wpływ na ostateczne wnioski z wewnątrzśrodowiskowych dyskusji miał Piasecki. Kolejnym organem było kilkudziesięcioosobowe kierownictwo Stowarzyszenia PAX, które poza sesjami plenarnymi pracowało w zespołach. Faktycznym ośrodkiem decyzyjnym było wyodrębnione Kierownictwo Ogólne w składzie: Bolesław Piasecki, Jerzy Hagmajer, Zygmunt Przetakiewicz, Dominik Horodyński, Konstanty Łubieński, Andrzej Krasiński, Zbigniew Czajkowski i Ryszard Reiff. Tak więc większość decyzji wiążących z punktu widzenia politycznego zapadała nie w liczacym ok. od 100 do 200 członków Zespole, ale podejmował je Piasecki i jego najbliżsi, oddani mu współpracownicy ${ }^{22}$.

Hierarchiczna struktura stowarzyszenia odpowiadająca „duchowi Falangi” - jak określił ją Andrzej Micewski - a także zapadające w PAX-ie jednoosobowe decyzje budziły opór części działaczy młodego pokolenia, wywodzących się głównie z ogniw kierowniczych. Domagali się oni przede wszystkim demokratyzacji i kolektywnych form kierowania organizacja. W obszernej, liczącej kilkadziesiąt stron maszynopisu, analizie stosunków panujących w stowarzyszeniu Jerzy Krasnowolski pisał:

\footnotetext{
${ }^{22}$ Archiwum Instytutu Pamięci Narodowej (dalej: AIPN), Bu 0201/260/1, Informacja dot. działalności PAX-u, Warszawa, 14 IV 1958, k. 21-25; AIPN, Bu 01283/1344, Informacja dot. bazy posiadania PAX-u, Warszawa, 27 XI 1953, k. 112-247; ibidem, Informacja dotycząca PAX-u (poprzednio grupa „Dziś i Jutro”), Warszawa 28 IX 1957, k. 258-259; J. Wójcik, Materiaty do historii ruchu spotecznie postępowego PAX, z. 4: Postawa ruchu spotecznie postepowego PAX $w$ trudnych latach stalinizmu $i$ pierwszych zapowiedziach odnowy socjalizmu (1951-1955 r.), Warszawa 1978, s. 40-48.
} 
Aksjomatem i główną wytyczną działalności Piaseckiego było i jest do chwili obecnej trzymanie się z grupa osób najbliższych przeważnie wywodzących się z dawnej „Falangi”, na czele katolickiego ruchu społecznie postępowego. Całym swoim postępowaniem udowadniają oni, że ponad dobro ogólne i interesy ruchu stawiaja zachowanie w swoim ręku wyłącznego kierownictwa. [...] w okresie, w którym wzrosła liczebność środowiska „Pax” i niewspółmiernie powiększył się zakres jego działalności, grupa zaufanych Piaseckiego stała się niezdolna do odpowiedzialnego kierowania ruchem. Jednocześnie dzięki naturalnej dynamice ruch wyłonił szereg nowych działaczy. Piasecki czując, że monopol jego i dyktatura są zagrożone i nie chcąc dopuścić do zdystansowania i zepchnięcia na drugi plan nikogo z otaczającej go kamaryli, zaczął prowadzić politykę personalną nie pokrywającą się z interesami ruchu, gwarantujacca, natomiast jemu i jego zaufanym zachowanie uprzywilejowanej pozycji. Dążenie za wszelką cenę ludzi nie posiadających dostatecznych kwalifikacji, których jedynym atutem były osobiste związki z Piaseckim, zmuszało do nieustannych zmian personalnych w środowisku, sprawiających wrażenie żonglerki. W praktyce oznaczało to faworyzowanie jednostek miernych i ograniczonych. [...] Typ przeważający w kierownictwie ścisłym - to typ, który trafniej należałoby określić mianem „ludzi Piaseckiego” niż działaczy ideowych, angażujących się z pozycji socjalistycznych i katolickich. Dla osób, które pragna pracować dla ruchu, ale nie chca przekształcić się w „ludzi Piaseckiego” nie ma w tej sytuacji perspektyw w środowisku. [...] Istniejący zespół kierowniczy nie zdolny jest do twórczego kierowania, a podejmowane w imieniu ich decyzje sa jednostkowymi decyzjami Piaseckiego bez udziału czynnika kolegialnego ${ }^{23}$.

Inny fakt, na który należy zwrócić uwagę, to słynna „sprawa indeksu”, czyli umieszczenie przez Watykan na „Indeksie Ksiag Zakazanych” głośnej książki B. Piaseckiego, pt. Zagadnienia istotne, i tygodnika „Dziś i Jutro”, którego pozbawiono przymiotnika „katolicki”"24. Przywołane Zagadnienia istotne (wyd. 1954) zawierały najważniejsze wypowiedzi programowe Piaseckiego drukowane na łamach prasy PAX-u w latach 1945-1953. Najwięcej wątpliwości budziła jednak „Przedmowa” - swoisty traktat filozoficzno-teologiczny, w której Piasecki zaprezentował wykładnię tzw. teologii oczywistości ziemskich,

${ }^{23}$ AIPN, Bu 0445/74/1, J. Krasnowolski, Środowisko PAX a katolicki ruch społeczno-postępowy w Polsce, Warszawa, 5 VIII 1955 r., k. 328-330. Zob. też: Wielkie sprzeniewierzenie. Oświadczenie bytych członków Stowarzyszenia PAX, „Po Prostu”, 11 XI 1956, nr 6, s. 2.

${ }^{24}$ Szerzej por. P. Raina, Piasecki na indeksie watykańskim. Geneza sprawy, Warszawa 2002; A. Micewski, Wspótrzadzić..., s. 68-72; J. Wójcik, op. cit., s. 181-194. Decyzji Kongregacji Świętego Oficjum próbowano przeciwdziałać na różne sposoby, wykorzystując m.in. pośrednictwo bpa Michała Klepacza (Przewodniczącego Konferencji Episkopatu Polski), który wysłał do Rzymu list na ręce kard. Pizzarda (Sekretarza Kongregacji Świętego Oficjum). List jednak pozostał bez odpowiedzi. Nie pomogła też wizyta w Rzymie Jerzego Hagmajera i Mikołaja Rostworowskiego (w maju 1956 r.) i ich rozmowy z Komisarzem Kongregacji Świętego Oficjum Paulem Philippe'em i cenzorem di Meglio. Zob. AIPN, Bu 01283/1344, Doniesienie agenturalne tajnego agenta „R”. Sprawa dekretu Świętego Oficjum, Warszawa, 26 VI1955, k. 413-417; ibidem, Doniesienie agenturalne tajnego agenta „Malicki”, Warszawa, 22 IV 1956, k. 422-423; ibidem, Doniesienie agenturalne tajnego agenta „Malicki”, Warszawa, 5 V 1956, k. 445-446. 
uzasadniając udział katolików w budowie socjalizmu ${ }^{25}$. Na niewiele zdały się próby mediacji z Watykanem. Ostatecznie zaniechano kolportażu książki Piaseckiego, a zamiast tygodnika „Dziś i Jutro” i „Tygodnika Powszechnego”, 20 V 1956 r. ukazał się pierwszy numer nowego tygodnika Stowarzyszenia PAX - „Kierunki”. Jednak w „sprawie indeksu” przyszli frondyści taktycznie zachowali lojalność wobec Piaseckiego i deklarowali zgodność poglądów $\mathrm{z}$ reszta kierownictwa ${ }^{26}$.

Jeszcze przed opublikowaniem Zagadnień istotnych niektórzy publicyści „Dziś i Jutro” przestrzegali Piaseckiego przed niedoprecyzowanymi i wielce kontrowersyjnymi tezami tam zawartymi. TW „Malicki” - jeden z najbardziej aktywnych i wpływowych agentów „na terenie katolickim” nie bez racji twierdził, że Piasecki tworząc zręby nowej ideologii stowarzyszenia, nie uwzględniał żadnych głosów krytycznych, zwłaszcza tych, które formułowali poirytowani „młodzi”, czyli późniejsza fronda ${ }^{27}$.

Dyktatorska postawa Piaseckiego jest źródłem błędów nie tylko w odniesieniu do polityki personalnej. Przesądza również w sposób całkowicie arbitralny zagadnienia ideowe ruchu. „Zagadnienia Istotne”, które postanowił uczynić podstawą teoretyczno-ideową ruchu i których jest autorem przed wydaniem nie były dyskutowane na żadnym zebraniu. Tymczasem w pracy tej Piasecki dał pewne sformułowania doktrynalne błędne lub nieścisłe. Wyrządził tym olbrzymią szkodę całemu ruchowi. Umożliwiło to bowiem zaczepienie i zaatakowanie tej pracy, a tym samym podstaw ideologicznych ruchu, z pozycji teologiczno-doktrynalnej przez koła watykańskie i reakcyjną część kleru. Mimo wskazania tych błędów Piasecki kierując się ambicja i w sposób awanturniczy narażając interesy ruchu upierał przy swoi[m] stanowisku. Popełniając poważny błąd polityczny i taktyczny, przeniósł punkt ciężkości dyskusji ideologicznej na zagadnienia teologiczne, gdzie nie miał ani autorytetu, ani kompetencji ${ }^{28}$.

Piasecki nie zamierzał tolerować wewnętrznego pluralizmu i w maju 1956 r. wcielił się w rolę cenzora. Chodziło o sprawę wycofania z „Dziś i Jutra” głośnego artykułu Władysława Seńki, pt. W jedności z Duchem Św.

${ }^{25}$ Zob. B. Piasecki, Przedmowa, w: idem, Zagadnienia istotne, Warszawa 1954 (również fragmenty w: idem, Kierunki 1945-1960, Warszawa 1981, s. 182-201); J. Wójcik, op. cit., s. 158-174; M. Rostworowski, Stowo o Paxie. 1945-1956, Warszawa 1968, s. 91; A. Dudek, G. Pytel, Bolesław Piasecki. Próba biografii politycznej, Londyn 1990, s. 214-216. Do wykładni Piaseckiego odniósł się również Zabłocki i co ważne, należał do jej krytyków. Por. J. Zabłocki, Katolicka inspiracja światopogladowa (I), „Dziś i Jutro”, 6 II 1955, nr 5, s. 1; idem, Katolicka inspiracja światopogladowa (II), „Dziś i Jutro”, 13 II 1955, nr 6, s. 2. Zob. tė̇: idem, Mazowiecki mój przeciwnik (15): Dekret Świętego Officjum, „Ład”, 10 II 1991, nr 6, s. 6.

${ }^{26}$ A. Micewski, Katolicy w potrzasku. Wspomnienia z peryferii polityki, Warszawa 1993, s. 40.

${ }^{27}$ AIPN, Bu 01283/1344, Notatka w sprawie sytuacji na terenie katolickim, Warszawa, 17 II 1956 r., k. 380.

${ }^{28}$ AIPN, Bu 0445/74/1, J. Krasnowolski, Środowisko PAX a katolicki ruch społeczno-postępowy w Polsce..., k. 340. 
(29 V 1955), stanowiącego wcale nie ostra i pryncypialna, a raczej niezwykle delikatna polemikę z Zagadnieniami istotnymi. Redaktor Zbigniew Czajkowski nie zapoznał się z tekstem i artykuł poszedł do druku. Dopiero po osobistej interwencji Piaseckiego wycofano z kolportażu ponad połowę nakładu (ok. 7 tys. egz.). Następnego dnia ukazał się drugi nakład z innym artykułem wstępnym. Cała, z pozoru błaha, sprawa wywołała zamieszanie i ataki na metody pracy w zespole. Seńko niemal natychmiast został usunięty z rozszerzonego kierownictwa PAX, Instytutu Wydawniczego, odebrano mu również kierownictwo w Wydziale Szkolenia i nadzór nad organizacją cyklicznie odbywajacych się Dni Społecznych w Halinie. Przeniesiono go do redakcji filozoficznej tygodnika „Dziś i Jutro”, jednak w pracach redakcji zawieszono go aż do odwołania. TW „Pielewski” (Jerzy Krasnowolski) donosił:

Piasecki całą sprawę dobił namawiając i inspirując ks. dziekana Kwiatkowskiego do napisania „listu” do redakcji: „W sprawie błędów w art. Seńki” - List był zupełnie bzdurny a zarzuty nonsensowne. Dodatkowo jeszcze ośmieszył Kwiatkowskiego i ostatecznie całą sprawą pogrążył. List został odebrany humorystycznie. [...] Ogólnie ludzie nie wierza, że „list” pisał rzeczywiście dziekan Kwiatkowski² ${ }^{29}$.

„Sprawa Seńki” wywołała wewnątrzśrodowiskowe tapnięcie. Za Seńka wstawili się Mazowiecki i Zabłocki, zaś ks. Henryk Michalski zrezygnował z dalszej współpracy z redakcja „Dziś i Jutra”. Trzeba jednak pamiętać, że postawa Mazowieckiego i Zabłockiego nie wynikała z krytycznej oceny Zagadnień istotnych, bo w tej materii zachowali wobec kierownictwa PAX-u daleko idącą lojalność, ale z obrony prawa do indywidulanej krytyki i swobody dyskusji. W liście napisanym do KC PZPR w sierpniu 1955 r. frondyści wyjaśnili swoje stanowisko w tej sprawie w sposób jednoznaczny i bez niedomówień. Zapewniali, że już od dawna w swojej publicystyce (casus Mazowieckiego) wyrażali krytyczne stanowisko wobec wrogiej polityki Watykanu.

Trzeba również uwzględnić fakt - czytamy dalej w liście do partii - że mimo iż dekret [Świętego Oficjum - T.S.] formalnie dotyczy tylko dwóch pozycji piśmienniczych jest on w interesie wrogich nam radiostacji i kół zachodnich rozciagany na całość ruchu społecznie postępowego katolików, na samą zasadę współdziałania katolików i marksistów, co służy demobilizowaniu ruchu społecznie postępowego, a w szczególności obliczone jest na zachwianie postawy społecznie postępowego duchowieństwa. W tej sytuacji reprezentowaliśmy w środowisku opinię, że byłoby niedobrze wciagać cały ruch $\mathrm{w}$ sytuację poczucia zagrożenia skutkami dekretu, wychodziłoby to bowiem naprzeciw tej właśnie rozszerzającej interpretacji ośrodków zagranicznych usiłujących za pośrednictwem swej propagandy wzbudzić nastroje chwiejności i niepokoju wśród duchowieństwa objętego oddziaływaniem Komisji. Zwracaliśmy również uwagę na

${ }^{29}$ Por. AIPN, Bu 01283/1344, Sprawa Frydrychewicz Anny. Wycią z doniesienia inf. „Pielewskiego” z 28 VI 1955 r., k. 498. Zob. też: ibidem, Wyciag z doniesienia TW „Bagarozzo”, Warszawa, 14 VIII 1955, k. 508; ibidem, Wyciąg z rozmowy Jerzego Turowicza z Władysławem Seńko, Warszawa, 11 VII 1955, k. 510. 
konieczność takiego rozwiązania zagadnienia dekretu, które nie dawałoby wrogim nam ośrodkom podstaw do zarzutu, że wykroczyliśmy poza granicę ortodoksji katolickiej. [...] Natomiast fakt ogłoszenia dekretu nie wpłynął w żadnym razie na osłabienie aktywności kogokolwiek z nas w ruchu społecznie postępowym ${ }^{30}$.

„Jednowładztwo”, brak demokratycznych metod zarządzania stowarzyszeniem i mieszanie polityki z religia (,integryzm religijno-polityczny”) wywoływały coraz większy środowiskowy ferment. Już jesienią 1954 r. zaczęły funkcjonować tzw. zespoły szkoleniowe, liczące ok. 15-40 osób, które na swoich zebraniach miały kanalizować głosy krytyczne, zapobiegając ujawnieniu ich na zebraniu plenarnym. Niezależnie od tego członkowie kierownictwa zobowiązani zostali, aby swoje wypowiedzi krytyczne ograniczali do form właściwych sobie instancji kierowniczych, a nie Zespołu. Tego typu działania miały na celu skazanie wszelkiej krytyki na bezskuteczność, co w konsekwencji prowadziło do sytuacji, że członkowie stowarzyszenia posiadając świadomość braku jakichkolwiek skutków ich wystapień, aby nie narazić się Piaseckiemu, zachowywali obojętność. Ten mechanizm zadziałał w nienagłaśnianej sprawie Stefana Czarneckiego - członka zespołu szkoleniowego, który na jednym z zebrań krytycznie ocenił metody pracy i błędy w zarządzaniu „Słowem Powszechnym”, za co został usunięty z zajmowanego przez siebie stanowiska w redakcji i zdegradowany. Powołana specjalnie na wniosek Piaseckiego komisja kontrolna podtrzymała decyzję w sprawie Czarneckiego ${ }^{31}$. Kolejnym wymownym przykładem świadczącym o braku wewnętrznego pluralizmu był przebieg zebrania plenarnego Zespołu, pod koniec maja 1955 r., na którym starano się wszelkimi metodami zapobiec dyskusji nad referatem głównym Piaseckiego.

Przeciwko „dyktatorskim” metodom Piaseckiego i ścisłego kierownictwa PAX-u już wiosna 1955 r. wystapili Mazowiecki i Zabłocki - liderzy wewnętrznej opozycji. Domagali się wewnątrzśrodowiskowej demokratyzacji, kolegialnych metod pracy, zerwania z „mafijnymi” praktykami, promowaniem na ważne stanowiska w stowarzyszeniu osób merytorycznie nieprzygotowanych, niewykształconych, bez dostatecznych kwalifikacji i doświadczenia. Spór dotyczył też postulatu rozłączenia spraw ideologicznych ze światopoglądowymi ${ }^{32}$.

${ }^{30}$ List „Frondy” do Komitetu Centralnego Polskiej Zjednoczonej Partii Robotniczej z dnia 14 sierpnia 1955 r., w: Z. Przetakiewicz, Od ONR-u do PAX-u. (Wspomnienia), Warszawa 1994 , s. $114-115$.

${ }^{31}$ AIPN, Bu 0445/74/1, J. Krasnowolski, Środowisko PAX a katolicki ruch społeczno-postępowy w Polsce..., k. 337-338.

32 Andrzej Micewski w spisanych po latach wspomnieniach twierdził, że oponenci Piaseckiego, którzy utworzyli frondę, występowali również przeciwko nacjonalizmowi promowanemu w PAX-ie przez byłych członków Konfederacji Narodu. Dyskusja w stowarzyszeniu na temat nacjonalizmu była niewygodna dla Piaseckiego, miał on bowiem świadomość, że wewnątrz środowiska istnieja koła, które mogłyby wykorzystać pronacjonalistyczne nastawienie ścisłego kierownictwa PAX do wewnętrznych rozgrywek. Micewski uważał, że Zabłocki w tej 
Fronda - jak celnie zauważył Andrzej Micewski - nie stanowiła jednolitej ideowo grupy. Łaczyły ja więzi towarzyskie i przyjacielskie oraz wspólny mianownik zamykający się w trzech zasadniczych punktach: „1) troska, aby PAX nie wkroczył na drogę mieszania autonomii religii i polityki, integryzmu, co w pewnym sensie już się stało; 2) podkreślenie momentów ideologicznych i moralnych w życiu Zespołu, tak katolickich, jak i socjalistycznych; 3) postawienie kwestii demokracji wewnętrznej w Zespole"33.

Piasecki miał się dowiedzieć o montowaniu opozycji wewnątrzśrodowiskowej od Przetakiewicza, który był obecny na ślubie Mazowieckiego i utrzymywał, że właśnie wówczas „zdemaskował frondę”34. 21 IV 1955 r. Tadeusz Mazowiecki na hucznie obchodzonych uroczystościach „10-lecia powrotu Ziem Zachodnich do Macierzy" po raz pierwszy publicznie wystapił z propozycja zmian organizacyjnych w stowarzyszeniu ${ }^{35}$. Kilka tygodni później, 17 V 1955 r. Mazowiecki i Zabłocki wystosowali oficjalny list - „memoriał” do Piaseckiego, w którym przedstawili program uzdrowienia sytuacji w PAX-ie. Proponowali

sprawie reprezentował już wówczas tzw. optykę narodowa, choć „wypłynęła ona” dopiero w drugiej połowie lat pięćdziesiątych. W omawianym okresie był to jednak temat „politycznie delikatny” - pisał Micewski. Por. A. Micewski, Katolicy w potrzasku..., s. 40-41. Pogląd Micewskiego zdecydowanie odrzuca Zabłocki, twierdząc, że kwestia nacjonalizmu Piaseckiego nie stanowiła wówczas podstawy wewnątrzśrodowiskowych sporów. Por. J. Zabłocki, Mazowiecki mój przeciwnik (9)..., s. 13; Załącznik do listu Janusza Zabłockiego do Tomasza Sikorskiego, 10 VII 2011 (w zbiorach prywatnych autora). Sprawa, którą wysuwano przy okazji krytyki stosunków panujacych w PAX-ie, był również daleki od socjalistycznego wzorca luksusowy styl życia części kierownictwa PAX-u (dysponowanie własnymi, nowymi samochodami, handel dewizami, kupowanie za pieniądze stowarzyszenia mieszkań dla lojalnych wobec Piaseckiego działaczy, wysokie gaże i wynagrodzenia za pracę w administracji). Wspominano również o dwuznacznych kontaktach Piaseckiego z kobietami (najczęściej wymieniano w tym kontekście: Janinę Kolendo - szwagierkę Piaseckiego, Barbarę Kopeć - rodzoną siostrę żony Piaseckiego i Teresę Englert - dyrektora Instytutu Wydawniczego PAX). W doniesieniach agenturalnych pojawiały się również informacje o libacjach alkoholowych organizowanych przez najbliższych współpracowników Piaseckiego. Por. np.: AIPN, Bu 0445/74/1, J. Krasnowolski, Środowisko PAX a katolicki ruch społeczno-postępowy w Polsce..., k. 332-333; AIPN, Bu 01283/1344, Notatka w sprawie sytuacji na terenie katolickim z doniesienia agenturalnego TW „Malicki”, Warszawa, 17 II 1956, k. 379-380; ibidem, Sprawa Frydrychewicz Anny. Wyciag z doniesienia inf. „Pielewskiego” z 28 VI 1955 r., k. 497; ibidem, Doniesienie agenturalne TW „Bross”, Warszawa, 15 V 1957, k. 572; ibidem, Doniesienie agenturalne TW „Wnuk”, Warszawa, 28 IX 1957, k. 589. Jerzy Hagmajer opierał „odchylenie” frondy Mazowieckiego i Zabłockiego na trzech zasadniczych punktach: „1. Nieakceptowanie zaangażowania socjalistycznego; 2. Wątpliwości, co do tezy o inspiracji chrześcijańskiej w życiu publicznym; 3. Filozoficzna akceptacja personalizmu mounierowskiego". Por. A. Dudek, G. Pytel, op. cit., s. 221.

${ }_{33}$ A. Micewski, Wspótrzqdzić..., s. 75.

${ }^{34}$ Ibidem, s. 75.

${ }_{35}$ T. Mazowiecki, Ziemie Zachodnie duma i nadzieja Polski. Fragment referatu red. Tadeusza Mazowieckiego wygtoszonego dn. 21.IV. br. we Wrocławiu podczas uroczystości 10-lecia powrotu Ziem Zachodnich do Macierzy, „Wrocławski Tygodnik Katolicki” 1955, nr 19, s. 3-6; J. Wójcik, op. cit., s. 195-196. 
m.in. zmianę struktury kierowania stowarzyszeniem. Miała ona polegać na zbliżeniu ogniw terenowych do centrali przez powołanie tzw. Poszerzonego Kierownictwa Organizacyjnego, które zbierałoby się cyklicznie (co najmniej sześć razy w roku) w składzie normalnego Kierownictwa Ogólnego, rozszerzonego o wszystkich wojewódzkich kierowników PAX-u, będących jednocześnie sekretarzami Komisji ${ }^{36}$. Propozycje frondy osłabiały nie tylko pozycję ścisłego kierownictwa PAX-u, ale również dawały autonomię ogniwom terenowym, na co Piasecki nie mógł się zgodzić. Już 7 IV 1955 r., podczas zebrania rozszerzonego kierownictwa PAX-u, Reiff (wówczas członek ścisłego kierownictwa stowarzyszenia i stronnik Piaseckiego) przestrzegał przed niebezpieczeństwem rozluźnienia kontaktu ze środowiskami terenowymi. Wyraził obawę, że poprzez efektywna pracę w radach narodowych poszczególni sekretarze będą sobie budowali w województwach niezależną wobec centrali pozycję, co w konsekwencji mogło zagrozić jedności PAX-u ${ }^{37}$. Trzeba pamiętać, że zarówno Mazowiecki, jak i Zabłocki posiadali duży autorytet w regionie (głównie na Ziemiach Zachodnich i Północnych), w lokalnych radach narodowych, oddziałach wojewódzkich „Słowa Powszechnego”, a także w Lublinie, gdzie działało bliskie PAX-owi Koło Społecznie Postępowe Studentów KUL. Mieli także swoich stronników w terenowych strukturach Komisji Duchownych i Świeckich Działaczy Katolickich przy Froncie Jedności Narodu (FJN).

W wyniku wewnętrznego fermentu późną wiosna 1955 r. doszło w PAX-ie do przesilenia. Piasecki nie zamierzał ustapić i chciał zdławić frondę w zarodku, tak aby „separatyści” nie urośli w siłę i nie zagrozili jedności ruchu. Ośrodkiem środowiskowej rewolty stali się redakcja i współpracownicy „Wrocławskiego Tygodnika Katolickiego": Stefan Bakinowski (sekretarz wrocławskiej Komisji Duchownych i Świeckich Działaczy Katolickich przy FJN, współpracownik „WTK”), Tadeusz Mazowiecki (redaktor naczelny „WTK”, członek kierownictwa PAX-u, radny Wojewódzkiej Rady Narodowej we Wrocławiu), Ignacy Rutkiewicz (członek kierownictwa PAX-u, redaktor „WTK”), Zofia Krall (kierownik działu religijnego „WTK”), Zygmunt Konieczny (sekretarz redakcji „WTK”), Stanisław Grochowiak (pracownik redakcji literackiej „WTK”, członek Koła Młodych Związku Literatów Polskich we Wrocławiu), Jerzy Krzysztoń (pracownik redakcji literackiej „WTK”, członek Koła Młodych ZLP we Wrocławiu), Jacek Łukasiewicz (pracownik redakcji literackiej „WTK”, członek Koła Młodych ZLP we Wrocławiu), Władysław Lech Terlecki (pracownik redakcji literackiej „WTK”, członek Koła Młodych ZLP we Wrocławiu) oraz pracownicy redakcji technicznej i administracji „WTK”. Jak informował TW „Jan”, na początku czerwca 1955 r. Bakinowski i Mazowiecki zażądali:

${ }^{36}$ Załącznik do listu Janusza Zabłockiego do Tomasza Sikorskiego, 10 VII 2011 (w zbiorach prywatnych autora).

${ }^{37}$ AIPN, Bu 0445/74/1, J. Krasnowolski, Środowisko PAX a katolicki ruch społeczno-postępowy w Polsce..., k. 336. 
usunięcia Piaseckiego z kierownictwa stowarzyszenia, zamknięcia tygodnika „Dziś i Jutro”, podporządkowania się w sprawie dekretu Świętego Oficjum Watykanowi, wycofania z kolportażu i bibliotek Zagadnien istotnych oraz odłączenia od PAX-u i pełnego usamodzielnienia „Wrocławskiego Tygodnika Katolickiego". 5 VIII 1955 r. Grochowiak i Terlecki w prywatnej rozmowie z TW „Janem” potwierdzili zamiary „separatystów”:

Są dwa aspekty tej sprawy: 1. Traktować groźbę klątwy na „Dziś i Jutro” i „Zagadnienia Istotne” jako rzecz odrębną i zerwać z innymi autorami piszącymi do tygodnika „Dziś i Jutro” starając się utrzymać pismo „Wrocławski Tygodnik Katolicki” jako oddzielne pismo grupy prowatykańskiej. Pismo to oficjalnie nie jest pismem PAX-u, a zarejestrowany jako wydawca jest fikcyjny Wrocławski Instytut Wydawniczy z Mazowieckim na czele. 2. Traktować potępienie jako potępienie całego ruchu społeczno-postępowego i w związku z tym zawiesić całkowicie działanie PAX-u. Wzór daje podobna historia we Francji. Oba wypadki łączy konieczność walki z oddaną „bez zastrzeżeń partii” grupą Piaseckiego ${ }^{38}$.

Rozmówcy TW „Jana” prosili również o wycofanie wszystkich tekstów przesłanych do redakcji „Dziś i Jutra”, zrywając współpracę z tygodnikiem. Na wniosek Mikołaja Rostworowskiego - redaktora naczelnego „Dziś i Jutra” i Zygmunta Przetakiewicza - redaktora naczelnego „Słowa Powszechnego” próbowano jeszcze ratować sytuację i przekonać „,separatystów”, aby wstrzymali się przed „puczem”. Bezskutecznie.

Mazowiecki i Bakinowski - niekwestionowani liderzy „grupy wrocławskiej” - uważali, że wewnątrzśrodowiskowy spór powinien wyjść poza rogatki stolicy Dolnego Śląska, i zdecydowali się na rozmowy sondażowe z członkami Zespołu, działaczami wojewódzkich oddziałów „Słowa Powszechnego” (głównie w Szczecinie, Koszalinie, Katowicach, Poznaniu, Wrocławiu, Gdańsku i Lublinie), z duchownymi z byłej Komisji przy Związku Bojowników o Wolność i Demokrację, gdzie mieli montować własne „skrzydło”. Frondowcy winni również pozostawać w ścisłym porozumieniu z Jerzym Roszakiem z KW PZPR we Wrocławiu oraz ks. infułatem Kazimierzem Langoszem z miejscowej kurii biskupiej ${ }^{39}$.

W przekonaniu Piaseckiego i jego stronników ze ścisłego kierownictwa Stowarzyszenia PAX sprawa „separatystów” nie była już tylko problemem „terenu”. Niemal natychmiast zareagowano i już 10 VI 1955 r. nałożono sankcje na liderów frondy - Mazowieckiego i Zabłockiego, pozbawiając ich wszystkich funkcji organizacyjnych. Mazowieckiego przeniesiono do Instytutu Wydawniczego PAX, a Zabłockiego na stanowisko sekretarza redakcji miesięcznika

38 AIPN, Bu 01283/1344, Doniesienie agenturalne TW „Jan”, Warszawa, 15 VIII 1955 r., k. 439.

${ }^{39}$ Ibidem, k. 437-438. Zob. też: ibidem, Notatka informacyjna w sprawie Tadeusza Mazowieckiego byłego redaktora WTK i sekretarza Komisji Działaczy przy WKFN, Wrocław, 9 VIII 1955 r., k. 547-549; ibidem, Doniesienie agenturalne TW „M”, Warszawa, 25 IX 1955, k. 553. 
„Życie i Myśl” ${ }^{40}$. Kilka dni później, 16 czerwca frondowcy próbowali jeszcze powrócić do wysuwanych postulatów mających uzdrowić panującą w PAX-ie atmosferę. W liście do Piaseckiego ponowili chęć porozumienia i „zagaszenia" konfliktu, ale jedocześnie konsekwentnie domagali się rozdzielenia religii i polityki (światopoglądu od ideologii), zwracali również uwagę na potrzebę demokratyzacji stosunków wewnątrzśrodowiskowych. Na list nie ma żadnej odpowiedzi ${ }^{41}$.

Rozłam w stowarzyszeniu był już tylko kwestią czasu. Przyśpieszyła go decyzja Świętego Oficjum w sprawie tygodnika „Dziś i Jutro” i głośnej książki Piaseckiego. W tej sytuacji Piasecki miał świadomość, że za frondą moga pójść działacze terenowi. Z drugiej strony wiedział już o tym, że Mazowiecki utrzymywał kontakt z czynnikami partyjno-rządowymi i zamierzał oderwać od stowarzyszenia „Wrocławski Tygodnik Katolicki”, a więc w jego przekonaniu działał przeciwko jedności ruchu postępowych katolików. Potwierdził to w rozmowie z Reiffem Franciszek Zając, kierownik referatu wyznaniowego w KC PZPR, który otrzymywał w tej sprawie informacje z KW PZPR we Wrocławiu. Decyzja o ostatecznym rozprawieniu się z frondą była w tym momencie już przesądzona.

9 VIII 1955 r. do Wrocławia przyjechał Mieczysław Kurzyna - członek specjalnej komisji, która miała wyjaśnić sprawę „buntu” grupy wrocławskiej. Na polecenie Przetakiewicza wydał decyzję w sprawie natychmiastowego przewiezienia dwoma samochodami do Warszawy: Bakinowskiego, Koniecznego, Grochowiaka, Łukasiewicza, Rutkiewicza i Terleckiego. Bakinowski i Mazowiecki poinformowali o poleceniu wyjazdu do stolicy sekretarza ds. propagandy Jerzego Roszaka z KW PZPR we Wrocławiu. Po przyjeździe do stolicy o godz. 22.30 wszyscy zostali poddani przesłuchaniu, które trwało cała noc i zakończyło się o 7 nad ranem. Komisji, która przesłuchiwała niepokornych członków PAX-u, przewodniczył Przetakiewicz. W jej skład wchodzili jeszcze: Rostworowski, Kurzyna, Bienkowski (dyrektor personalny Instytutu Wydawniczego PAX). W kolejnych dniach (10 i 11 VIII) odbyły się przesłuchania Bakinowskiego, któremu zabroniono kontaktować się z osobami trzecimi. W trakcie przesłuchania przedkładano mu kilkakrotnie wcześniej zredagowane protokoły, jakoby przyznał się do udziału w separatystycznej grupie, której zamiarem było rozbicie jedności w Stowarzyszeniu PAX. 11 VIII na polecenie Piaseckiego mieli się stawić w późnych godzinach wieczornych inni działacze PAX-u, podejrzani o działalność „wywrotowa”: Buchała, Drozdek, Zabłocki, Wieczorek i Mazowiecki. Czekającym na przesłuchanie przed siedmioosobową komisją (Hagmajer, Przetakiewicz, Horodyński, Kurzyna, Reiff,

${ }^{40}$ J. Zabłocki, Mazowiecki mój przeciwnik (14): Poczqtki odwilży, „Ład”, 3 II 1991, nr 5, s. 6.

${ }^{41}$ AIPN, Bu 01283/1344, Doniesienie agenturalne TW „M”, Warszawa 28 IX 1955 r., k. 553; Załącznik do listu Janusza Zabłockiego do Tomasza Sikorskiego, 10 VII 2011 (w zbiorach prywatnych autora); A. Micewski, Wspótrzqdzić..., s. 77; M. Rostworowski, op. cit., s. 97-98. 
Łubieński) z Piaseckim na czele zabroniono kontaktować się z otoczeniem i poddano nadzorowi pracownika administracyjnego PAX-u, który przebywał z nimi w tym samym pokoju, rejestrując przebieg rozmowy. Przesłuchiwanych pytano o zaufanie do ścisłego kierownictwa PAX-u, więzi z fronda, o stosunki panujace $\mathrm{w}$ Zespole ${ }^{42}$. Wszyscy przesłuchiwani w mniejszym lub większym stopniu zachowali wzajemna solidarność i krytycyzm wobec metod pracy w stowarzyszeniu. Starano się unikać doktrynalnych sporów na temat Zagadnień istotnych i dekretu Świętego Oficjum, zachowując taktyczną lojalność z kierownictwem PAX-u. Rozpoczęte o godz. 22.00 przesłuchanie zakończyło się wczesnym rankiem następnego dnia (o godz. 7 rano). 13 VIII wydano postanowienie mówiące o „wyobcowaniu kolegów z jednolitej więzi ideowej środowiska" i nałożono wachlarz represji środowiskowych. W uzasadnieniu stwierdzano, że przesłuchiwani wykazali się negatywną postawą w Zespole, naruszyli wewnętrzne zasady pracy i bezpodstawnie przedstawiali krytyczna ocenę rzekomo niezdrowych stosunków w środowisku i błędów popełnionych przez kierownictwo ${ }^{43}$. Jeszcze tego samego dnia o godz. 19, na zebraniu rozszerzonego kierownictwa PAX-u, Piasecki podał do wiadomości informację o działalności w ramach środowiska nieformalnej grupy separatystycznej, której udowodniono zarzuty działania wbrew ruchowi katolików postępowych. Jednocześnie świadomie utajnił część dokumentacji z przesłuchania, która mogłaby się okazać niewygodna ${ }^{44}$. Niewątpliwie Piaseckiemu zależało na

${ }^{42}$ Przesłuchiwanym zarzucano również kontakty z bezpieką i Hugonem Hankem, premierem rządu na uchodźstwie (maj-sierpień 1955), który w 1955, jako członek wywiadu PRL o kryptonimie „Ważny”, powrócił do kraju. Por. AIPN, Bu 01283/1344, Doniesienie agenturalne TW „Malicki”, Warszawa, 25 VI 1956, k. 425; ibidem, Meldunek specjalny Naczelnika Wydziału IV W.U. ds. W/UBP kpt. Z. Sikory do Dyrektora Departamentu IV Komitetu ds. Bezpieczeństwa Publicznego, Wrocław, 15 X 1955, k. 558; ibidem, Meldunek operacyjny Naczelnika Wydziału VI W.U. ds. BP w Olsztynie kpt. M. Sałkowskiego do Dyrektora Departamentu VI Komitetu do Spraw Bezpieczeństwa Publicznego w Warszawie, Olsztyn, 15 IX 1955, k. 544; List „Frondy” do Komitetu Centralnego Polskiej Zjednoczonej Partii Robotniczej, Warszawa, 14 X 1955 r., w: Z. Przetakiewicz, Od ONR-u do PAX-u..., s. 122; S. Cenckiewicz, Udziat aparatu bezpieczeństwa PRL w drugiej kampanii reemigracyjnej (1955-1957), w: idem, Śladami bezpieki i partii, Łomianki 2009, s. 75-77; N. Wójtowicz, Kryptonim „Mikron”. Bezpieka wobec Juliusza Sokolnickiego, Poznań 2015, s. 111; Żyliśmy nadzieja. Z bytym Prezydentem Rzeczypospolitej Ryszardem Kaczorowskim rozmawia Tomasz Danilewski, „Biuletyn Instytutu Pamięci Narodowej” 2002, nr 3, s. 31.

${ }^{43}$ AIPN, Bu 01283/1344, Doniesienie agenturalne TW „Jan”, Warszawa, 15 VIII 1955 r., k. 440-442; ibidem, Notatka informacyjna w sprawie Tadeusza Mazowieckiego byłego redaktora WTK i sekretarza Komisji Działaczy przy WKFN, Wrocław, 9 VIII 1955 r., k. 547; J. Zabłocki, Mazowiecki mój przeciwnik (16): Rozprawa z „Fronda”, „Ład”, 17 II 1991, nr 7, s. 6; Załącznik do listu Janusza Zabłockiego do Tomasza Sikorskiego, 10 VII 2011 (w zbiorach prywatnych autora); A. Micewski, Wspótrzadzić..., s. 76; List „Frondy” do Komitetu Centralnego Polskiej Zjednoczonej Partii Robotniczej z dnia 14 sierpnia 1955..., s. $110-111$.

${ }^{44}$ Por. ibidem, s. 111. 
rozbiciu grupy, a jednocześnie utrzymaniu wśród kierownictwa stowarzyszenia przekonania, że fronda prowadziła działalność nie przeciwko Piaseckiemu i jego stronnikom, ale przeciw stowarzyszeniu. Fronda jednak taktycznie nie atakowała Piaseckiego, do końca uznając jego niekwestionowane przywództwo. Argumentowano, że chodzi jedynie o zasady i metody kierowania organizacja.

Ostatnią kwestia, która budziła niepokój Piaseckiego, były kontakty frondy z partią. Jak podaje Micewski - wówczas wpływowy działacz PAX-u - już od jesieni 1954 r. członkowie frondy niejednokrotnie konferowali z tow. Zajacem z KC PZPR i Marianem Zygmanowskim, kierownikiem Urzędu do Spraw Wyznań ${ }^{45}$. Nie przyjął frondystów tow. Franciszek Mazur - członek Biura Politycznego KC PZPR, który nie mógł się zdecydować, co począć z fronda, czy podtrzymać rozłam w PAX-ie ${ }^{46}$. Taka postawa była niewątpliwie na rękę Piaseckiemu, „fronda” bowiem nie miała pewności, jak zachowa się partia, kogo ostatecznie poprze.

14 VIII 1955 r. działacze frondy wystosowali list do KC PZPR (na ręce tow. Mazura), w którym precyzyjnie przedstawili, z zachowaniem wierności najmniejszym detalom, „przebieg wydarzeń”. Ponownie podniesiono

45 Z Marianem Zygmanowskim kontaktował się również Jerzy Krasnowolski, który już wiosną 1955 r. nawiązał stosunki z fronda. W doniesieniu agenturalnym TW „M” czytamy: „W tym czasie do owej grupy Mazowieckiego i Zabłockiego zbliżył się Krasnowolski, który wyjaśnił tamtym, że jego zdaniem w okresie dekretu nie należy występować oficjalnie tylko należy przycichnać. Natomiast zaproponował, żeby w sprawie wystapienia oficjalnego wystapiły władze partyjne. Zaproponował też, że skomunikuje się w tej sprawie z kier. Wydziału do Spraw Wyznań dla miasta stołecznego Warszawy Leśniewskim. Po czym udał się do Leśniewskiego i przedstawił mu całą sprawę Frondy. Leśniewski stwierdził, że ponieważ sprawa dotyczy całej Polski a nie tylko Warszawy i jest bardzo poważna, więc najlepiej aby Krasnowolski przedstawił ją ministrowi Zygmanowskiemu, z którym ofiarował się go skontaktować. Minister Zygmanowski wyznaczył rozmowę na odpowiednią godzinę, tymczasem w poczekalni Krasnowolski zetknął się przypadkowo z Micewskim, jednym z najbliższych współpracowników Piaseckiego. Minister Zygmanowski przyją Krasnowolskiego bardzo zainteresował się jego postulatem i polecił mu, aby opracował duży memoriał na temat sytuacji w PAX-ie, gdyż jak się wyraził jest to sprawa bardzo ważna dla KC i Biura Politycznego. Krasnowolski opracował taki memoriał i złożył go ministrowi Zygmanowskiemu”. AIPN, Bu 01283/1344, Doniesienie agenturalne TW „M”, Warszawa, 25 IX 1955, k. 553-554. Według frondystów poprawki w memoriale Krasnowolskiego nanosił Zabłocki, a zatem jego treść musiała być konsultowana z fronda. Por. List „Frondy” do Komitetu Centralnego Polskiej Zjednoczonej Partii Robotniczej, Warszawa, 14 X 1995..., s. 122-123. Liczący ponad 20 stron maszynopisu memoriał Krasnowolskiego z 5 VIII 1955 r. zawierał analizę sytuacji w Stowarzyszeniu PAX. Diagnoza Krasnowolskiego, poparta rozlicznymi przykładami, pokrywała się w dużej mierze z ocenami wysuwanymi przez frondę. Memoriał kończyła lista konkretnych postulatów mających uzdrowić atmosferę w stowarzyszeniu (m.in. wewnętrzna demokratyzacja stosunków panujących w PAX-ie, kolektywne metody pracy, likwidacja monopolu Piaseckiego i jego stronników w ścisłym kierownictwie stowarzyszenia). Por. AIPN, Bu 0445/74/1, J. Krasnowolski, Środowisko PAX a katolicki ruch społeczno-postępowy w Polsce..., k. 343-344.

46 A. Micewski, Wspótrzqdzić..., s. 77. 
środowiskowe postulaty demokratyzacji stosunków panujących w PAX-ie, ograniczenia tendencji dyktatorskich, mafijnych praktyk, wprowadzenia kolegialnych zasad zarządzania stowarzyszeniem. Jednocześnie taktycznie deklarowano pełną lojalność wobec Piaseckiego. Pisano:

Uznawaliśmy istniejące kierownictwo Zespołu PAX z Bolesławem Piaseckim na czele i uznajemy je do tej chwili; ale uznanie przez nas tego kierownictwa i podporządkowanie się mu nie może być przez nie nadużywane w kierunku pozbawienia nas prawa krytyki jego pociagnięć tam, gdzie kierownictwo to zapomina o swoim charakterze służebnym wobec celów ideowo-politycznych, które ma realizować i gdzie przypisuje sobie wartość celu samego w sobie. Uznanie kierownictwa Bolesława Piaseckiego i ludzi z jego otoczenia oraz podporządkowanie się im nie może być przez nich samych utożsamiane z obowiązkiem naszej uległości i bezkrytycznej aprobaty dla popełnianych przez nich błędów. Nie może być również utożsamiane z uległością i bierną aprobatą dla takich obciążeń w stylu kierowania jak skłonność do arbitralnych decyzji, pogarda nawet pozorów kolegialności, dygnitarstwo i burżuazyjny, konsumpcyjny styl życia, które stanowią relikty faszystowskiej przeszłości tych ludzi - kompromitują w opinii zewnętrznej nasze środowisko i osłabiają siłę jego oddziaływania na duchowieństwo, a w samym ruch[u] stają się od dłuższego czasu przyczyną zrażania i odtrącania od współpracy z nami szeregu cennych ludzi ${ }^{47}$.

Sygnatariuszem listu był trzon frondy. Oprócz Mazowieckiego tworzyli go jeszcze: Stefan Bakinowski (sekretarz komisji wojewódzkiej PAX-u we Wrocławiu, od 1952 r. czł. Zespołu, czł. Prezydium Wojewódzkiego FJN we Wrocławiu), Rudolf Buchała (sekretarz komisji wojewódzkiej PAX-u w Katowicach, od 1951 r. czł. Zespołu, czł. Prezydium Wojewódzkiego FJN w Katowicach), Zygmunt Drozdek (czł. zespołu tygodnika „Dziś i Jutro”, redaktor pisma „Katolik” w Opolu, od 1952 r. czł. Zespołu, od 1953 r. sekretarz wojewódzkiej Komisji Intelektualistów i Działaczy Katolickich w Katowicach, w latach 1953-1955 asystent katedry ekonomii politycznej i nauki o Polsce współczesnej na KUL), Tadeusz Myślik (sekretarz komisji wojewódzkiej PAX-u w Krakowie, od 1952 r. czł. Zespołu, radny WRN w Krakowie) $)^{48}$.

List frondy do KC PZPR nie przyniósł żadnych rezultatów. Partia nie zamierzała włączać się bezpośrednio w sprawy PAX-u. Pozycja Piaseckiego, po spotkaniu z Bolesławem Bierutem 12 VIII 1955 r., również wydawała się niezachwiana $^{49} .3$ IX $1955 \mathrm{r}$. Wojciech Wieczorek w imieniu całego środowiska frondy wystosował kolejny list do Piaseckiego. Wyrażając pełne zaufanie wobec kierownictwa stowarzyszenia, proponował wznowienie merytorycznej dyskusji nad atmosfera w PAX-ie. Zapowiadał, że fronda jest gotowa do

${ }^{47}$ List „Frondy” do Komitetu Centralnego Polskiej Zjednoczonej Partii Robotniczej z dnia 14 sierpnia $1955 \ldots$, s. 112.

${ }^{48}$ Listu nie podpisali: Zabłocki, Rutkiewicz i Wieczorek. Por. Załącznik do listu Janusza Zabłockiego do Tomasza Sikorskiego, 10 VII 2011 (w zbiorach prywatnych autora).

${ }^{49}$ Por. J. Dobraczyński, Wspomnienie, „Kultura, Oświata, Nauka. Miesięcznik Stowarzyszenia PAX” 1985, nr 3-4, s. 145; A. Dudek, G. Pytel, op. cit., s. 217. 
naprawy stosunków panujacych w środowisku, uzdrowienia sytuacji. Warunek wznowienia rozmów stanowiło jednak przywrócenie pluralizmu, kolegialności i zasad demokratycznych w podejmowaniu decyzji przez kierownictwo stowarzyszenia. Taktycznie również zapowiadał, że zarówno on, jak i jego koledzy skłonni są do wyrażania „samokrytycznej oceny własnych błędów” 50 . Argumentacja Wieczorka nie przekonała Piaseckiego, który żadnych rozmów z frondą nie zamierzał już prowadzić. 9 IX 1955 r. ścisłe kierownictwo stowarzyszenia wydało nowe zarządzenie, w którym można było przeczytać, iż Bakinowski, Zabłocki, Mazowiecki, Myślik, Buchała, Wieczorek i Rutkiewicz „nie ujawnili w swoim postępowaniu zrozumienia ideowo-wychowawczego sensu postanowienia kierownictwa z 13 sierpnia br., zawiesza się ich w prawach członka Zespołu Stowarzyszenia PAX do czasu złożenia indywidualnej samokrytyki odpowiadającej "Wytycznym»" ${ }^{51}$. Złożenie samokrytyki było dla frondy warunkiem nie do przyjęcia. 14 X 1955 r. po raz kolejny liderzy frondy wystosowali list do KC PZPR, w którym zarysowali ogólne podłoże konfliktu wewnętrznego w PAX-ie. Bronili własnego stanowiska, wzywając do kolektywnej kontroli posunięć kierownictwa stowarzyszenia (,grupy monopolistycznej"). W przekonaniu frondy naprawa stosunków wewnątrzśrodowiskowych byłaby możliwa tylko poprzez „wprowadzenie elementarnych założeń kolektywnego stylu pracy i decyzji oraz zasady krytyki i samokrytyki jako podstawowych socjalistycznych zasad stylu pracy i kierowania" ${ }^{52}$. Mając świadomość pozostawania już poza PAX-em, sygnatariusze listu deklarowali, że nie zamierzają prowadzić wobec stowarzyszenia działań antagonistycznych. Kierownictwo partii proszono o możliwość dalszej pracy w ramach Frontu Narodowego ${ }^{53}$. Po raz ostatni w grudniu 1955 r. Zabłocki wysłał jeszcze pojednawczy list do Kętrzyńskiego, w którym proponował mu pośrednictwo w powrocie frondy do PAX-u. Piasecki nie zamierzał jednak wracać do sprawy już definitywnie zakończonej ${ }^{54}$.

W ślad za faktycznym wykluczeniem frondystów z PAX-u pozbawiono ich pracy $\mathrm{w}$ instytucjach związanych ze stowarzyszeniem. 17 września wypowiedzenie otrzymał Bakinowski, 29 września - Myślik, 4 października - Mazowiecki, a tydzień później: Wieczorek, Buchała, Drozdek, Rutkiewicz

50 AIPN, Bu 01283/1344, List Wojciecha Wieczorka do Bolesława Piaseckiego, Warszawa, 3 IX 1955, k. 265-267.

51 J. Zabłocki, Mazowiecki mój przeciwnik (16)..., s. 6; Załącznik do listu Janusza Zabłockiego do Tomasza Sikorskiego, 10 VII 2011 (w zbiorach prywatnych autora); A. Micewski, Wspótrzqdzić..., s. 77; AIPN, Bu 0201/260/1/297/IV, Informacja dot. działalności PAX-u, Warszawa, 14 IV 1958, k. 16; AIPN, Bu 01521/2092, J. Huk, Stowarzyszenie PAX, praca magisterska napisana pod kierunkiem płk. dr Józefy Siemaszkiewicz, Warszawa 1984, k. 39.

${ }^{52}$ List „Frondy” do Komitetu Centralnego Polskiej Zjednoczonej Partii Robotniczej, Warszawa, 14 X $1955 \ldots$, s. 123.

${ }^{53}$ Ibidem, s. 125.

${ }^{54}$ Załącznik do listu Janusza Zabłockiego do Tomasza Sikorskiego, 10 VII 2011 (w zbiorach prywatnych autora); A. Micewski, Wspótrzadzić..., s. 77. 
i Zabłocki. Z listy członków PAX-u w ciagu niespełna dwóch miesięcy skreślono również: Krasnowolskiego, Juliusza Eskę, Aleksandra Ejsmonda i innych działaczy „z terenu”. Za sympatyzowanie z frondą z dotychczasowych funkcji $\mathrm{w}$ stowarzyszeniu usunięto i przeniesiono na mniej eksponowane stanowiska (czasami do „pracy terenowej”): Grochowiaka, Terleckiego, Krzysztonia, Krall, Koniecznego, Łukasiewicza, Adama Śnieżka, Leona Brodowskiego, Macieja Kononowicza i wielu innych ${ }^{55}$. Jeszcze przez kilka miesięcy frondyści, formalnie już poza PAX-em, pozostawali w wojewódzkich strukturach FJN, WRN oraz terenowych ogniwach Komisji Intelektualistów i Działaczy Katolickich ${ }^{56}$. Następnie przez wiele miesięcy trwali nie tylko w „politycznej hibernacji”, ale przede wszystkim zostali pozbawieni pracy i źródeł zarobkowania. Dopiero po niemal rocznej przerwie Zabłocki trafił do redakcji miesięcznika „Nasza Ojczyzna", wydawanego przez Towarzystwo Łączności z Wychodźstwem „Polonia”. Wkrótce do pracy w towarzystwie dołączył również Mazowiecki ${ }^{57}$. Zaś Zygmunt Drozdek, wykorzystując stare towarzyskie koneksje, otrzymał „posadę” asystenta prof. Tadeusza Kotarbińskiego ${ }^{58}$.

Postępujący proces odwilży wiosna 1956 r. zaktywizował młodą inteligencję, również tę o proweniencji katolickiej. W spontaniczny sposób na terenie całego kraju zaczęły ujawniać się rozdyskutowane i rozpolitykowane środowiska. Działacze katoliccy uwzględniali współpracę z frondą w różnych konstelacjach. Jeszcze w lutym 1956 r. Zdzisław Szpakowski, były członek Koła Społecznie Postępowego Studentów KUL i kandydat do Zespołu Stowarzyszenia PAX, prowadził rozmowy sondażowe na temat budowy organizacji katolików świeckich, która stanowiłaby alternatywę dla PAX-u. Program nowego ruchu miał być oparty na akceptacji ustroju socjalistycznego i różnic światopoglądowych między „obozem katolików, a obozem marksistów”. Szpakowski zakładał, że do nowo formowanego ruchu mogliby wejść: młodzi działacze Stronnictwa Pracy, dawni publicyści „Tygodnika Warszawskiego”

55 AIPN, Bu 01283/1344, Doniesienie agenturalne TW „Malicki”, Warszawa, 23 VIII 1956, k. 450; ibidem, Meldunek specjalny Naczelnika Wydziału IV W.U. ds. W/UBP kpt. Z. Sikory do Dyrektora Departamentu IV Komitetu ds. Bezpieczeństwa Publicznego, Wrocław 15 X 1955, k. 558; ibidem, Doniesienie agenturalne TW „M”, Warszawa 26 VII 1955, k. 416; J. Zabłocki, Mazowiecki mój przeciwnik (17): „Fronda” $i$ jej intelektualne zaplecze, „Ład”, 13 I 1991, nr 2, s. 6; Załącznik do listu Janusza Zabłockiego do Tomasza Sikorskiego, 10 VII 2011 (w zbiorach prywatnych autora); List „Frondy” do Komitetu Centralnego Polskiej Zjednoczonej Partii Robotniczej, Warszawa, 14 X 1955..., s. 121-122. Por. też: B. Bankowicz, A. Dudek, Ze studiów nad dziejami Kościoła i katolicyzmu w PRL, Kraków 1996, s. 79-90.

${ }^{56}$ W lutym 1956 r. Reiff z polecenia Piaseckiego, ale za sugestią Zajacca z KC PZPR wysunął w stosunku do frondy ofertę dalszej współpracy w Komisji Duchownych i Świeckich Działaczy Katolickich przy FJN oraz pracę w instytucjach Stowarzyszenia PAX. Por. AIPN, Bu 01283/1344, Doniesienie agenturalne TW „Malicki”, Warszawa, 22 II 1956, k. 389.

${ }^{57}$ M. Strzelecka, op. cit., s. 132.

${ }^{58}$ R. Graczyk, op. cit., s. 67. 
(głównie członkowie „Kolumny Młodych”), działacze Sodalicji Mariańskiej (np. Krasnowolski, Wacław Auleytner), „postępowa” młodzież z KUL-u (grupa Ryszarda Bendera), reprezentanci „katolickiego” skrzydła w Zjednoczonym Stronnictwie Ludowym (grupa posła Stanisława Cieślaka), członkowie dawnej grupy „Etap” (środowisko skupione wokół Zbigniewa Zaborskiego) oraz pojedynczy intelektualiści katoliccy, jak np. Jacek Wejroch, Andrzej Grzegorczyk, Juliusz Eska. Lewicę ruchu stanowiłaby fronda, choć Szpakowski miał świadomość, że udział grupy Mazowieckiego i Zabłockiego mógłby wywoływać opory tzw. katolickiej prawicy, do których zaliczał byłych chadeków i młodzież akademicką z Lublina. W każdym razie liczono, że w dalszej perspektywie ruch otrzymałby koncesję na prowadzenie własnej spółdzielni wielobranżowej i instytutu wydawniczego, wydawanie społeczno-politycznego tygodnika katolickiego. W stosunku do PAX-u środowisko formowane przez Szpakowskiego miało zachować neutralnośćs ${ }^{5}$. Członkowie frondy rzeczywiście uczestniczyli w rozmowach ze Szpakowskim, wysuwali jednak sporo zastrzeżeń do „prawicowej” (,integrystycznej”) formuły nowego ruchu ${ }^{60}$. Poza tym legalizacja w tym czasie alternatywnej wobec PAX-u organizacji katolików świeckich wydawała się mało realna, stąd zdecydowano się na formułę klubowa. Działacze frondy już na przełomie marca i kwietnia 1956 r. uformowali wieloświatopoglądowy Klub Okragłego Stołu, zrzeszający lewicę katolicka, rewizjonistów partyjnych. Nawiązano też współpracę z redakcją „Po Prostu”, partyjnymi liberałami i Klubem Krzywego Koła ${ }^{61}$. Już po październiku 1956 r. klub odszedł od „ideowego eklektyzmu” i jego działacze, głównie z frondy, zainicjowali działalność zorientowanego na personalizm Klubu im. Emmanuela Mouniera.

Janusz Zabłocki wszedł też do powołanego w kwietniu 1956 r. pięcioosobowego sekretariatu Krajowego Ośrodka Współpracy Klubów Inteligencji przy Ogólnopolskim Komitecie Frontu Narodowego. Wojciech Wieczorek i Danuta Zabłocka-Skupieńska zostali członkami redakcji „Nowego Nurtu” - biuletynu wydawanego przez ośrodek ${ }^{62}$. W lutym $1956 \mathrm{r}$. zarejestrowano również Klub „Dialog”, któremu udało się nawet w 1957 r. wydać dwa numery własnego biuletynu. Po nieudanej próbie rejestracji w formule stowarzyszenia, w styczniu 1958 r. został rozwiązany, a jego uczestnicy włączyli się w prace

${ }^{59}$ Por. AIPN, Bu 01283/1344, Notatka w sprawie sytuacji na terenie katolickim z doniesienia agenturalnego TW „Malicki”, Warszawa, 17 II 1956, k. 383-387; ibidem, Doniesienie agenturalne TW „Malicki”, Warszawa, 22 II 1956, k. 389; ibidem, Doniesienie agenturalne TW „Malicki” (Odgłosy wokół dyskusji o XX Zjeździe KPZR), Warszawa, 5 IV 1956, k. 400.

${ }^{60}$ Załącznik do listu Janusza Zabłockiego do Tomasza Sikorskiego, 10 VII 2011 (w zbiorach prywatnych autora).

${ }^{61}$ AIPN, Bu 01283/1344, Doniesienie agenturalne TW „Malicki”, Warszawa, 14 IV 1956, k. 403; Załącznik do listu Janusza Zabłockiego do Tomasza Sikorskiego, 10 VII 2011 (w zbiorach prywatnych autora).

62 J. Zabłocki, Mazowiecki mój przeciwnik (19): W ruchu klubów inteligencji, „Ład”, 10 III 1991, nr 10, s. 6. 
warszawskiego Klubu Inteligencji Katolickiej ${ }^{63}$. Wkrótce na terenie całego kraju podobnych inicjatyw powstało znacznie więcej, by przywołać tylko Klub Inteligencji „Odrodzenie”, Akademicki Klub Katolików, Klub „Ognisko”, Klub „Start”, Katolicki Klub Pracy. Do pracy środowiskowej włączali się byli działacze „Odrodzenia”, Sodalicji Mariańskiej, członkowie Stronnictwa Pracy, publicyści, którzy jeszcze do niedawna wybrali „wewnętrzną emigracje”" Więzienia opuszczali represjonowani przez reżim stalinowski redaktorzy i współpracownicy „Tygodnika Warszawskiego”. W większych miastach, ale nie tylko, powstawały lokalne kluby inteligencji katolickiej. W szczytowym okresie było ich ponad $30^{64}$. Słowem, pozostajaca poza PAX-em inteligencja katolicka powoli wychodziła z katakumb.

Rozłam w PAX-ie niewątpliwie uruchomił wewnątrzśrodowiskowy ferment, zwłaszcza w strukturach terenowych stowarzyszenia. Co prawda pozycja Piaseckiego i ścisłego kierownictwa ruchu pozostała niezachwiana, także dlatego, że nadal mieli oni poparcie aparatu partyjnego, to jednak w stowarzyszeniu cały czas pojawiały się głosy krytyki, które w okresie „goracego” października 1956 r. nabrały bardziej konkretnych kształtów. Na trzy dni przed zbliżającym się „legendarnym” VIII Plenum KC PZPR Piasecki opublikował na łamach „Słowa Powszechnego” kontrowersyjny artykuł pt. Instynkt państwowy, w którym wyraźnie stanał po stronie „frakcji natolińskiej” i wzywał do puczu, zahamowania procesów demokratyzacji65. Tekst spotkał się z lawinową krytyką polskiej prasy, miał też nieodwracalne

${ }^{63}$ Idem, Chrześcijańska Demokracja w kraju i na emigracji 1947-1970, Lublin 1999, s. 144145. Klub „Dialog” od początku swojego istnienia był kontrolowany operacyjnie przez SB. Co najmniej czterech jego członków zostało informatorami bezpieki. Do najgroźniejszych należeli: TW „Wolski” i TW „Nowak” oraz Jerzy Krasnowolski. W materiałach bezpieki występuje on jako informator o pseudonimie „M” i „Stefan”, a także TW „Pielewski”. Zob. AIPN: Bu 0648/86, t. I; Bu 01251/22; Bu 00170/917, t. I-III; Bu 01236/1218; Bu 01236/1520; Bu 01208/2018; Bu 01208/2019. Zob. też: AIPN, Bu 0648/114, Informacja dot. klubu katolickiego „Dialog”, Warszawa, 1 IX 1957, k. 144; AIPN, Bu 0648/86, t. I, Informacja dot. klubu katolickiego „Dialog”, Warszawa, X 1957, k. 74-75. O agenturalnej działalności Krasnowolskiego pisali m.in.: T. Krok, Antymasońska komórka Episkopatu Polski w świetle badań i dokumentów (1946-1952), Gdynia-Kraków 2015 (zwł. rozdz. II); A. Friszke, Między wojna a więzieniem..., s. 298-308; idem, Nadzieje i złudzenia. Środowiska katolików świeckich przed i po październiku 1956 roku, w: Sensus catholicus..., s. 98-100.

${ }^{64}$ Zob. J. Zabłocki, Dzienniki 1956-1965, t. I, Warszawa 2008, s. 28-58; idem, Chrześcijańska Demokracja..., s. 139-140; idem, Mazowiecki mój przeciwnik (19)..., s. 6; idem, W ruchu klubów inteligencji, „Ład”, 10 III 1991; A. Friszke, Oaza na Kopernika. Klub Inteligencji Katolickiej 1956-1989, Warszawa 1997, s. 48; idem, Poczqtki Klubów Inteligencji Katolickiej, „Więź” 1996, nr 19, s. 181-204; P. Kaźmierczak, Klub Inteligencji Katolickiej w Krakowie w latach 1956-1989, Kraków 2009, s. 16; P. Ceranka, Warszawskie Kluby Dyskusyjne, w: Warszawa miasto $w$ opresji. Warszawa niepokonana, red. K. Krajewski, M. Pietrzak-Merta, Warszawa 2010, s. 392-419.

65 B. Piasecki, Instynkt państwowy, „Kierunki”, 21 X 1956, nr 23, s. 1-2. 
w skutkach konsekwencje dla PAX-u ${ }^{66}$. Najpierw ze stowarzyszenia wystapiła grupa „młodych” publicystów „Słowa Powszechnego”, następnie prominentni działacze (np. Jan Frankowski, Konstanty Łubieński, Andrzej Micewski, Wojciech Kętrzyński), którzy jeszcze do niedawna należeli do stronników Piaseckiego ${ }^{67}$. Nad stowarzyszeniem pojawiło się całkowicie realne widmo likwidacji. Dopiero 2 I 1957 r., gdy Władysław Gomułka przyją Piaseckiego, zapewnił go, że PAX zachowa dotychczasowe koncesje. Stowarzyszeniu udało się przetrwać najcięższy okres w swojej dotychczasowej działalności.

\section{Streszczenie}

Artykuł stanowi próbę wielopłaszczyznowego (głównie ideowego, programowego i organizacyjnego) ukazania podłoża wewnątrzśrodowiskowego konfliktu w Stowarzyszeniu PAX, który w 1955 r. doprowadził do poważnego w skutkach rozłamu. W pierwszej części tekstu skoncentrowano uwage na genezie grupy, która opuści PAX. Przeanalizowano „wczesna”” publicystykę polityczną (z lat 1948-1954) liderów późniejszej frondy: Tadeusza Mazowieckiego i Janusza Zabłockiego, eksponując podstawowe wektory ich ideowo-politycznej tożsamości. Ukazano również proces krystalizowania się „ruchu młodych” wewnątrz PAX-u, który zakwestionował zarówno wewnętrzny sposób zarządzania organizacja, jak również promowaną przez Bolesława Piaseckiego koncepcję współzależności ideologii, religii i polityki. Zabłocki nazwał ją sporem o „immanencję polityczną”. Opowiadał się wespół z Mazowieckim za pluralizmem światopoglądowym jako alternatywą dla wszelkich totalizmów (także światopoglądowych) i integryzmów (także katolickich). Katolicy winni przede wszystkim służyć socjalizmowi w imię zasady, iż nie ma chrześcijańskiej polityki, a jedynie chrześcijańska odpowiedzialność polityczna w życiu publicznym. W drugiej części artykułu dokonano analizy procesu wewnętrznej dekompozycji Stowarzyszenia PAX, który doprowadził do opuszczenia jego szeregów przez tzw. frondę. Omówiono zarówno podstawowe źródła konfliktu (postulaty wewnętrznej demokratyzacji PAX-u, zerwania $\mathrm{z}$,dyktatorskimi” metodami zarządzania, niełączenia spraw wiary i światopoglądu z polityką itd., jak też przebieg wewnętrznego sporu,

${ }^{66}$ Prawie wszystkie te ataki prasowe na PAX zostały kilka miesięcy później opublikowane w miesięczniku „Życie i Myśl” (w rubryce: „Dokumenty”). Por. Dokumenty, „Życie i Myśl” 1956, nr 4-5; 1957, nr 1. Zob. też: T. Sikorski, Prasa centralna Stowarzyszenia PAX wobec „odwilży” $i$ „polskiego października” 1956 roku, s. 27-44 (mps).

${ }^{67} \mathrm{~W}$ końcu 1956 r. prominentni działacze PAX-u utworzyli tzw. secesję, która uzyskała koncesje na wydawanie własnego tygodnika „Za i Przeciw”, a następnie przekształciła się w Związek Chrześcijańsko-Społeczny (1957), później w Chrześcijańskie Stowarzyszenie Społeczne, dysponujące własną bazą gospodarczą (Ars Christiana) i „koncertem” prasowym. Por. T. Sikorski, Orientacje ideowo-polityczne środowisk katolików świeckich w Polsce (1956 -1972), w: Dzieje Kościoła katolickiego na Pomorzu Zachodnim, t. II: 1956-1972, red. M. Siedziako, Z. Stanuch, ks. G. Wejman, Szczecin-Warszawa 2017, s. 101-140; Kronika X-lecia Chrześcijańskiego Stowarzyszenia Społecznego, „Studia i Dokumenty” 1967, nr 1; A. Friszke, Nadzieje i ztudzenia..., s. 100-106; idem, Opozycja polityczna w PRL 1945-1980, Londyn 1994, s. 189-194; D. Gucewicz, Dywersyjna działalność Chrześcijańskiego Stowarzyszenia Społecznego w ruchu katolickim (na przyktadzie Gdańska), w: Sensus catholicus..., s. 627-634. Zob. też: C. Kuta, „Działacze” i,Pismaki”. Aparat bezpieczeństwa wobec organizacji katolików świeckich w Krakowie w latach 1957-1989, Kraków 2009, s. 321-376; A. Micewski, Katolicy w potrzasku..., s. 47-50. 
z uwzględnieniem optyki dwóch stron konfliktu. Równie istotne były relacje między frondą a KC PZPR (także KW PZPR we Wrocławiu). Przedstawiono również konsekwencje rozłamu w PAX-ie oraz dalsze działania uczestników frondy na kilka miesięcy przed wydarzeniami października 1956 r. Tekst oparty został przede wszystkim na materiale źródłowym różnej proweniencji. Opracowania naukowe pełniły jedynie rolę pomocniczą.

\section{Fronda. The split in the PAX Association in 1955 (its genesis - course - consequences)}

The article is an attempt at multi-faceted (mainly ideological, programmatic and organizational) presentation of the underlying causes of the internal conflict within the PAX Association, which in 1955 led to a split with serious consequences. The first part focuses on the origins of the group which would leave PAX, analysing the "early" political journalism (1948-1954) of the later leaders of the Fronde: Tadeusz Mazowiecki and Janusz Zabłocki, revealing the basic vectors of their ideological and political identity. It shows the process of crystallization of the "youth movement" inside PAX - which would question both the internal management of the association, and the concept - promoted by Boleslaw Piasecki - of interdependence of ideology, religion and politics. Zabłocki called it a dispute about the "political immanence". Together with Mazowiecki, he advocated for the pluralism of worldview as an alternative to a totalitarianism (also an ideological one) and fundamentalism (also a Catholic one). Catholics were supposed to serve socialism in the name of the principle that there was no such a thing as Christian politics, but there was only a political responsibility in public life of Christians. The second part of the article analyses the process of internal decomposition of the PAX Association, which led the so-called Fronde to leave its ranks. The text discusses both the basic causes of the conflict (demands for its internal democratization, for its breaking with the "dictatorial" management methods, for not combining faith and worldview with politics, etc.), and its internal course, seen from the both sides. Equally important were the relations between the Fronde and the Central Committee of the Polish United Workers' Party (also the Wrocław Voivodship Committee of the PUWP). It also presents the consequences of the split and further actions of the Fronde members, only few months before the Polish October of 1956. The text is based mainly on the source material of various origin. The secondary literature has played only a supporting role.

\section{Bibliografia}

Bankowicz B., Dudek A., Ze studiów nad dziejami Kościoła i katolicyzmu w PRL, Kraków 1996. Brzeziecki A., Tadeusz Mazowiecki. Biografia naszego premiera, Kraków 2015.

Cenckiewicz S., Udziat aparatu bezpieczeństwa PRL $w$ drugiej kampanii reemigracyjnej (1955-1957), w: idem, Śladami bezpieki i partii, Łomianki 2009, s. 51-89.

Ceranka P., Warszawskie Kluby Dyskusyjne, w: Warszawa miasto w opresji. Warszawa niepokonana, red. K. Krajewski, M. Pietrzak-Merta, Warszawa 2010, s. 392-419.

Dudek A., Pytel G., Bolesław Piasecki. Próba biografii politycznej, Londyn 1990.

Friszke A., Między wojna a więzieniem 1945-1953. Mtoda inteligencja katolicka, Warszawa 2015.

Friszke A., Nadzieje i złudzenia. Środowiska katolików świeckich przed i po październiku 1956 roku, w: Sensus catholicus. Katolicy świeccy w Polsce Ludowej. Postawy - aktywność - myśl. Studia i szkice, red. R. Ptaszyński, T. Sikorski, Toruń 2014.

Friszke A., Oaza na Kopernika. Klub Inteligencji Katolickiej 1956-1989, Warszawa 1997.

Friszke A., Opozycja polityczna w PRL 1945-1980, Londyn 1994.

Graczyk R., Od uwiktania do autentyczności. Biografia polityczna Tadeusza Mazowieckiego, Poznań 2015. 
Gucewicz D., Dywersyjna działalność Chrześcijańskiego Stowarzyszenia Społecznego w ruchu katolickim (na przykładzie Gdańska), w: Sensus catholicus. Katolicy świeccy w Polsce Ludowej. Postawy - aktywność - myśl. Studia i szkice, red. R. Ptaszyński, T. Sikorski, Toruń 2014.

Kaźmierczak P., Klub Inteligencji Katolickiej w Krakowie w latach 1956-1989, Kraków 2009. Krok T., Antymasońska komórka Episkopatu Polski w świetle badań $i$ dokumentów (19461952), Gdynia-Kraków 2015.

Kuta C., „Działacze” i „Pismaki”. Aparat bezpieczeństwa wobec organizacji katolików świeckich $w$ Krakowie $w$ latach 1957-1989, Kraków 2009.

Przytulski F., „Obok wież Kościołów, kominy fabryk”. Działalność publicystyczna Tadeusza Mazowieckiego $w$ latach 1947-1955, w: Sensus catholicus. Katolicy świeccy w Polsce Ludowej. Postawy - aktywność - myśl. Studia i szkice, red. R. Ptaszyński, T. Sikorski, Toruń 2014.

Raina P., Piasecki na indeksie watykańskim. Geneza sprawy, Warszawa 2002.

Strzelecka M., Między minimalizmem a maksymalizmem. Dylematy ideowe Stanistawa Stommy i Janusza Zabłockiego, Torun 2015.

Wójtowicz N., Kryptonim „Mikron”. Bezpieka wobec Juliusza Sokolnickiego, Poznań 2015.

Biogram: Tomasz Sikorski - dr hab., historyk, politolog, profesor Uniwersytetu Szczecińskiego, pracownik Instytutu Historii i Stosunków Międzynarodowych US, Ośrodka Badań Biograficznych US, autor i współautor kilkudziesięciu książek. Obszar zainteresowań: historia ruchów politycznych i społecznych, myśl polityczna, historia idei, biografistyka, kultura (zwłaszcza literatura i film) a polityka, ideologia. E-mail: t.sikorski@poczta.fm. 